This article was downloaded by: [University of Exeter]

On: 15 July 2015, At: 09: 43

Publisher: Routledge

Informa Ltd Registered in England and Wales Registered Number:

1072954 Registered office: 5 Howick Place, London, SW1P IWG

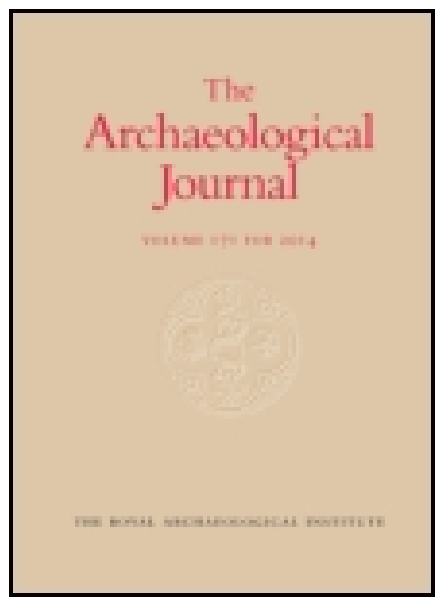

Archaeological J ournal

Publication details, including instructions for authors and subscription information:

http:/ / www. tandfonline.com/loi/ raij20

\title{
The Roman Circus in Britain: Some New Identifications
}

A. Hadrian Allcroft M. A.

Published online: $17 \mathrm{~J}$ ul 2014.

To cite this article: A. Hadrian Allcroft M. A. (1919) The Roman Circus in Britain: Some New Identifications, Archaeological J ournal, 76:1, 96-132, DOl: 10.1080/ 00665983. 1919.10853337

To link to this article: http:/ / dx. doi.org/ 10.1080/ 00665983. 1919.10853337

\section{PLEASE SCROLL DOWN FOR ARTICLE}

Taylor \& Francis makes every effort to ensure the accuracy of all the information (the "Content") contained in the publications on our platform. However, Taylor \& Francis, our agents, and our licensors make no representations or warranties whatsoever as to the accuracy, completeness, or suitability for any purpose of the Content. Any opinions and views expressed in this publication are the opinions and views of the authors, and are not the views of or endorsed by Taylor $\&$ Francis. The accuracy of the Content should not be relied upon and should be independently verified with primary sources of information. Taylor and Francis shall not be liable for any losses, actions, claims, proceedings, demands, costs, expenses, damages, and other liabilities whatsoever or howsoever caused arising directly or indirectly in connection with, in relation to or arising out of the use of the Content.

This article may be used for research, teaching, and private study purposes. Any substantial or systematic reproduction, redistribution, reselling, loan, sub-licensing, systematic supply, or distribution in any form to anyone is expressly forbidden. Terms \& Conditions of access 
and use can be found at http://www.tandfonline.com/page/termsand-conditions 


\section{THE ROMAN CIRCUS IN BRITAIN : SOME NEW IDENTIFICATIONS. ${ }^{1}$}

By A. HADRIAN ALLCROFT, M.A.

The subject of the following article is a class of earthworks which has excited curiosity and baffled speculation from the days of Stukeley. It will be shown that the type is of wide distribution in Britain, that its distinctive characteristics are rigid, that they are capable of explanation; and there will be advanced an entirely novel theory of its purpose. Certain far-reaching corollaries which follow must be reserved for another occasion.

\section{§I.-THE TYPE.}

The type under consideration (fig. I) shows the following features:-

i. The plan is that of a circle or an ellipse enclosed within an earthen vallum, having either one entrance, or two entrances at opposite points.

ii. The floor of the arena so enclosed is purposely sunk below the natural surface-level, the soil thus removed providing the material for the vallum.

iii. There is no exterior fosse.

iv. The vallum is usually of very slight external relief, rising somewhat higher on either side of the entrance-ways, the sill of which is the natural surface-level.

v. The inner slope of the vallum is very gradual.

vi. The type is commonly associated with the unmistakable remains of ancient settlements. It is found occasionally within the area of such settlements, but more usually just without the gate thereof, and in immediate contiguity to the road of access thereto.

vii. The surface soil commonly yields scraps of pottery of Romano-British character, but no other remains.

${ }^{1}$ Read before the Institute, 7 th May, 1919. 


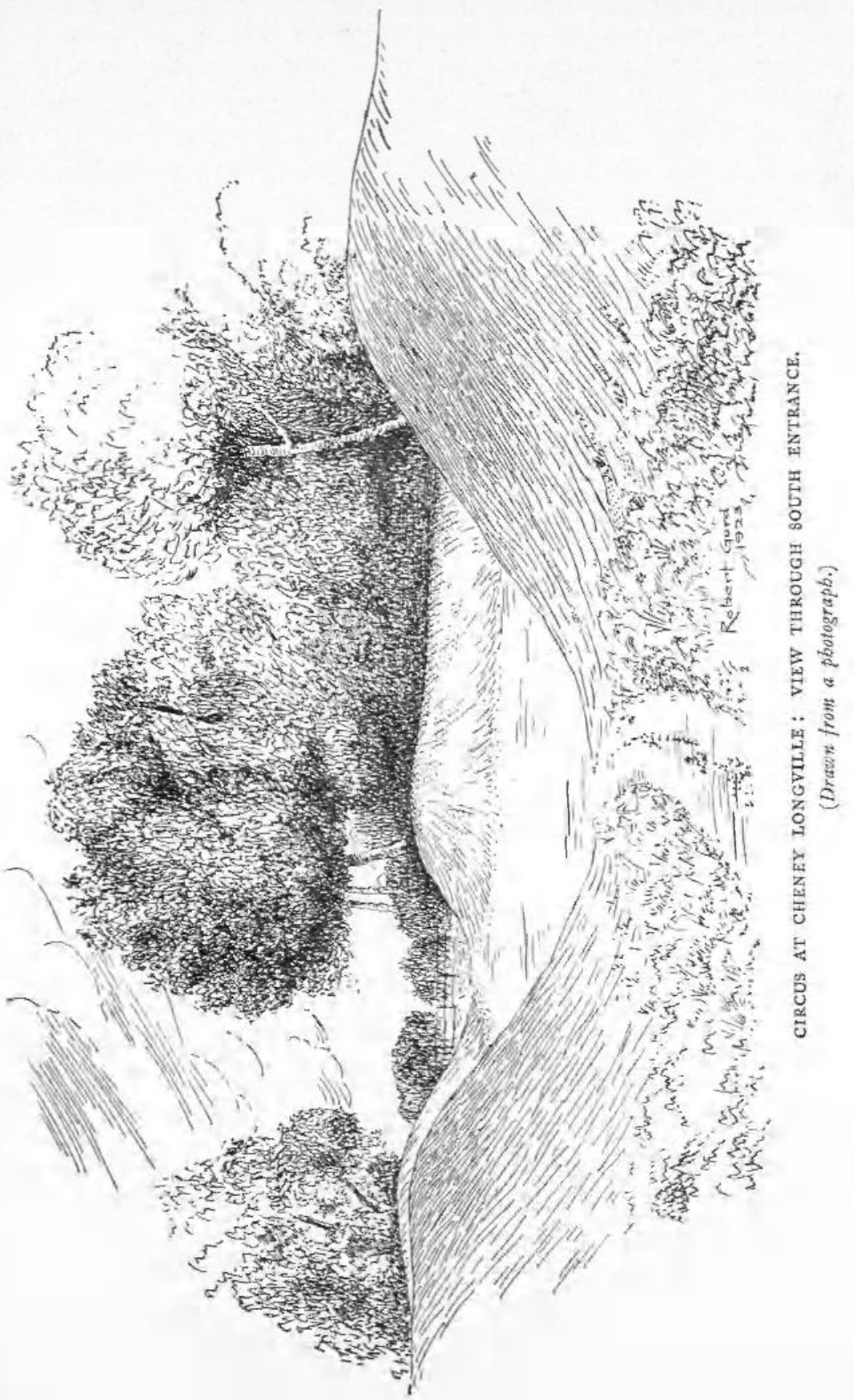


A transverse section shows a saucer-like depression (cavea) enclosed within banks of slight relief, but of disproportionate breadth. This cavea may range in diameter from less than $65 \mathrm{ft}$. to as much as $250 \mathrm{ft}$. or more, the mean being from 70 to $80 \mathrm{ft}$. In the latter, the average depth of the floor (at centre) below the natural surface is from 2 to $3 \mathrm{ft}$., the vallum rising from 4 to $7 \mathrm{ft}$. above it. As
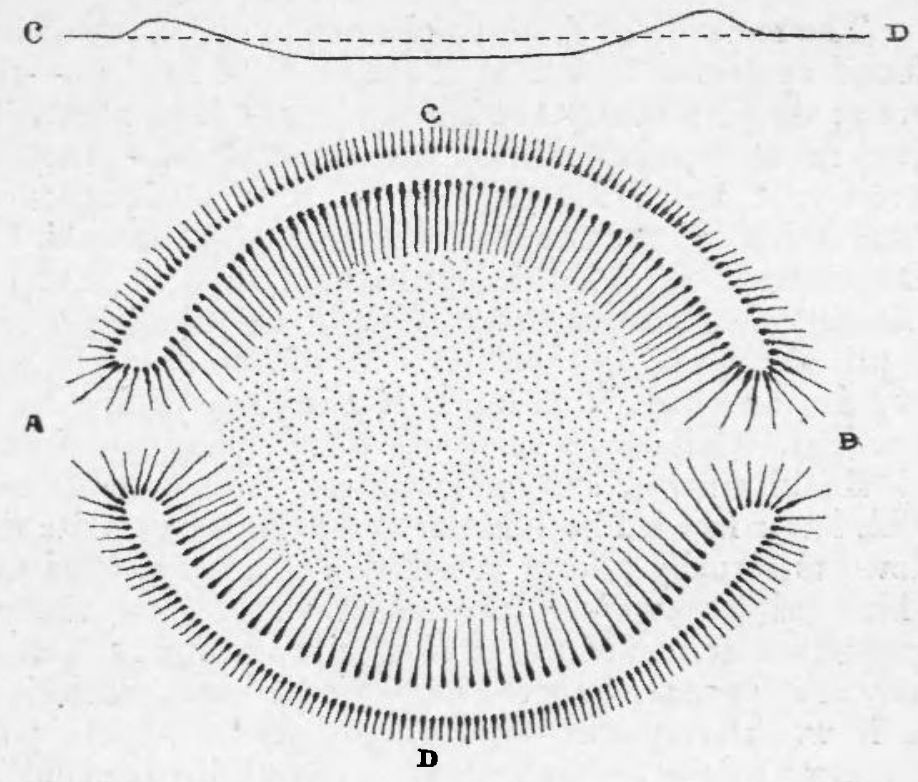

A

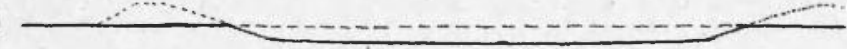

FIG. I. THE TYPE.

most of the examples have been ploughed over at one time or other, the consequent spread of the vallum makes very difficult any exact measurement of its width, which may be anything from $20 \mathrm{ft}$. upward. In not a few cases the original features have been so much destroyed that what remains may easily pass for the site of an abandoned pond ${ }^{1}$ or of a pit made in digging for chalk, gravel, sand, or stone,

\footnotetext{
${ }^{1}$ Some have, perhaps, been converted into ponds. This was actually about to happen with the great circus on Chettle 
or even of a swallet. Its real character may, however, even in extreme cases, frequently be gathered from the finding of fragments of Romano-British pottery upon the surface, if not from the presence in the vicinity of more obtrusive indications of a settlement, such as roads, lynchets, and barrows.

\section{\$ 2.-PREVIOUS NOTICES AND THEORIES.}

The majority of the examples at present recorded being found upon the chalk areas of the south of England-there are at the present day not less than eight to be seen within one area of 25 square miles of Cranborne Chase 1-they have necessarily drawn the attention of those antiquaries who have written about the anhistoric remains of Wiltshire and Dorsetshire. Stukeley makes casual allusion to them : he noticed one about one mile NW. of Stonehenge, $7 \mathrm{ft}$. in depth and $90 \mathrm{ft}$. in diameter, ' a circular dish-like cavity dug in the chalk,' ${ }^{2}$ adding that there was a fine barrow beside it. Colt Hoare mentions them as frequent features of 'British villages,' and commonly associated with barrows. ${ }^{3}$ This latter fact led both Hoare and Stukeley to write them down as actually a form of barrow : Stukeley called them ' inverted barrows' - if the reader will reverse the page and glance at any of the sections given in figs. I, 4 and 7 , he will at once see that the name was as exactly descriptive as it was unfortunate-and Hoare, styling them 'pondbarrows,' figures one as 'Type no. vi in his list of sepulchral forms. ${ }^{4}$ Fosbroke, quoting Hoare's remark about their

1 These are as follows :

i. Church barrow, Woodcuts, diam. $66 \mathrm{ft}$.

ii. Oakley lane, $75 \mathrm{ft}$; 1 mile S. of no. 1.

iii. Berwick down, 70 by $60 \mathrm{ft}$; 2 miles NW. of no. I.

iv. Gussage down, $60 \mathrm{ft}$; 3 miles SE. of no. 1 .

v. Chettle down, 176 by $146 \mathrm{ft}$. ; 2 miles SSW. of no. 1.

vi. Tarrant Hinton down, 85 by $75 \mathrm{ft}$. ; r $\frac{1}{2}$ miles S. of no. 5 .

vii. South Tarrant Hinton down, 120 by $100 \mathrm{ft}$. ; $1 \frac{1}{2}$ miles SSW. of no. 5 .

viii. Oakley down, not measured; $3 \frac{1}{2}$ miles E. of no. 1 .

Of these eight all are well preserved, excepting no. 1 , which is half destroyed, and nos. 2 and 8 . The latter is reduced to a mere pit in a ploughed field, but the remains of the "village' to which it belonged are marked upon the Ordnance map.

2 Abury, p. 12 ; Stonebenge, p. 45.

3 Ancient Wilts, p. 80. His plans of British oppida are too perfunctory to be adduced as evidence.

- The figure (Ancient Wilts, p. 22) shows a saucer-shaped depression ringed by a vallum, but having no fosse and also no entrances. Precisely similar works are figured in the plate (p. 121) showing the barrows at Winterbourne Stoke, and again in that (p. 207) of the barrows on Wilsford down; and in each case the letterpress calls them 'pond-barrows.' 
association with ' British villages,' adds that their position in relation to the settlement is very much that of a modern church in relation to its village. ${ }^{1}$ Stukeley and Hoare both admit that they had never found any sepulchral remains within works of this type, and Stukeley, evidently feeling the weakness of his 'barrow' theory, surmised in other cases that the works had some ceremonial purpose; and, still obsessed by the fact that they are so often associated with

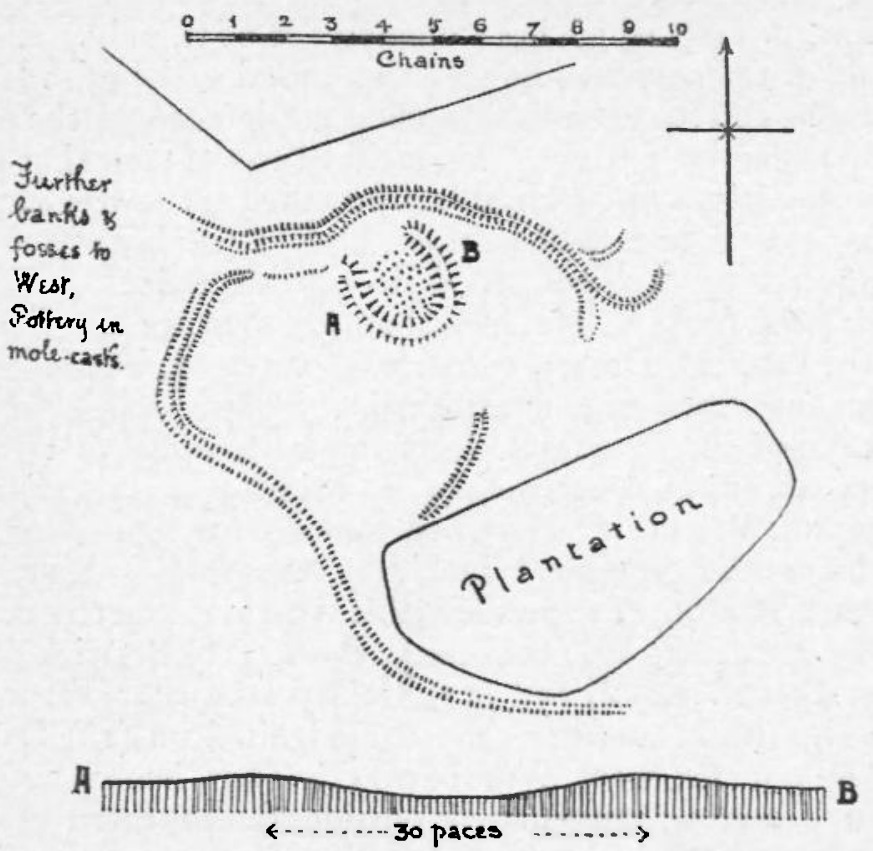

FIG. 2. TARRANT HINTON DOWN : REMAINS OF SETTLEMENT WITH CIRCUS.

what appear to be actual barrows, at last advanced the theory that they had been built as the scenes of funeral sports and games. Thurnam ${ }^{2}$ approved this view, and the further guess that they had originally been provided with a roof. Daniel Wilson regarded them as "the remains of primitive dwellings.' 3 Warne ${ }^{4}$ quarrelled with the

1 Encyclopaedia of Antiquities, p. 569 .

2 Arcbacologia, xlii (1869), p. 166.

3 Prebistoric Scotland (1851), p. 43.

4 Ancient Dorset (1872), p. 43, etc.; $V$ estiges ( 1865$),$ pp. $4^{6-48}$; and Celice
Tumuli of Dorset. His language in speaking of examples on Winterbourne Abbas down and Steepleton down is proof that he is dealing with what Hoare called 'pondbarrows.' Nevertheless, he seems occasionally to refer to them as iumuli. 
sepulchral theory, and preferred to call them 'sacred circles of earth'; a name which Dr. Colley March'1 adopted, adding that such works were to be found 'all over England.' Warne mentions at least seven specific examples at (1) the 'British village' of Turnworth, (2) on Winterbourne Came down, (3) on Broad Mayne down, and (4) at Buzbury. The last-named is shown upon his plan of the oppidum ${ }^{2}$ : it accords exactly with the type, but was, he says, very small, 'not much more than half the size of Church barrow' (below, p. I I6), which has a diameter of $66 \mathrm{ft}$. only. A mile north of the oppidum, he says there used to be (5) a larger example, and (6) yet a sixth outside the defences of the great camp of Badbury Rings. ${ }^{3}$ He inclined to the view that they were ' religious or juridical,' or intended for sports such as cock-fighting and bull-baiting; but once he was overpersuaded by a friend to style one of them ' a Celtic Corseddau (sic).' ${ }^{4} \mathrm{He}$ mentions (7) another on Ballard down, Panfield, Dorset, which was excavated, but failed to yield any trace of an interment. ${ }^{5}$ Dr. Colley March mentioned three examples from the western end of Dorsetshire, viz. (8) at Askerswell, (9) at Bridehead, and (10) near Compton Valence. ${ }^{4}$ Heywood Sumner has figured several in his earlier volume, ${ }^{6}$ including examples at (I I, I 2) Tarrant Hinton, (13) Swallowcliffe, and (I4) Chettle down. There are others at (15) Gussage down, (I6) Berwick down near Tollard Royal, and (17) Oakley lane near Farnham, and the site of another can be recognised on (I8) Oakley down, not far from Wor barrow. That known as (I9) Church barrow, immediately outside the southern gate of the Romano-British town of Woodcuts, was partially explored by Pitt-Rivers, ${ }^{7}$ who determined it to be of a date subsequent to the Roman Conquest. It was strictly circular, with a diameter of $66 \mathrm{ft}$. only, the vallum rising $5 \mathrm{ft}$. above the interior. M. A. Lower records ${ }^{8}$ that some-

1 Proc. Dorset N.H. and Antiq. Field Club, xxix (1908), p. 243.

2 Ancient Dorset, plate i. He speaks of that on Broad Mayne down as having been rectangular, but it is not clear that he had ever seen it. The proven Romano-British amphitheatre at Charterhouse-on-Mendip has a decidedly square appearance under certain conditions, although there is in reality nothing square about it.

${ }^{3}$ Ancient Dorset. p. $3^{6 .}$
4 estiges, pp. 15,46 . This was the work one mile N. of Buzbury.

- Proceedings Dorset N. H. and Antiq. Field Club, xxix (1908), p. 243.

- Eartbworks of Cramborne Cbase, plates xx, xxi, xxiv, xxvii, xliv.

'Excavations in Cranborne Cbase, i, p. 23 and plate iii.

${ }^{8}$ Sussex Arcbaeol. Collections, xviii (1866 p. 2. 


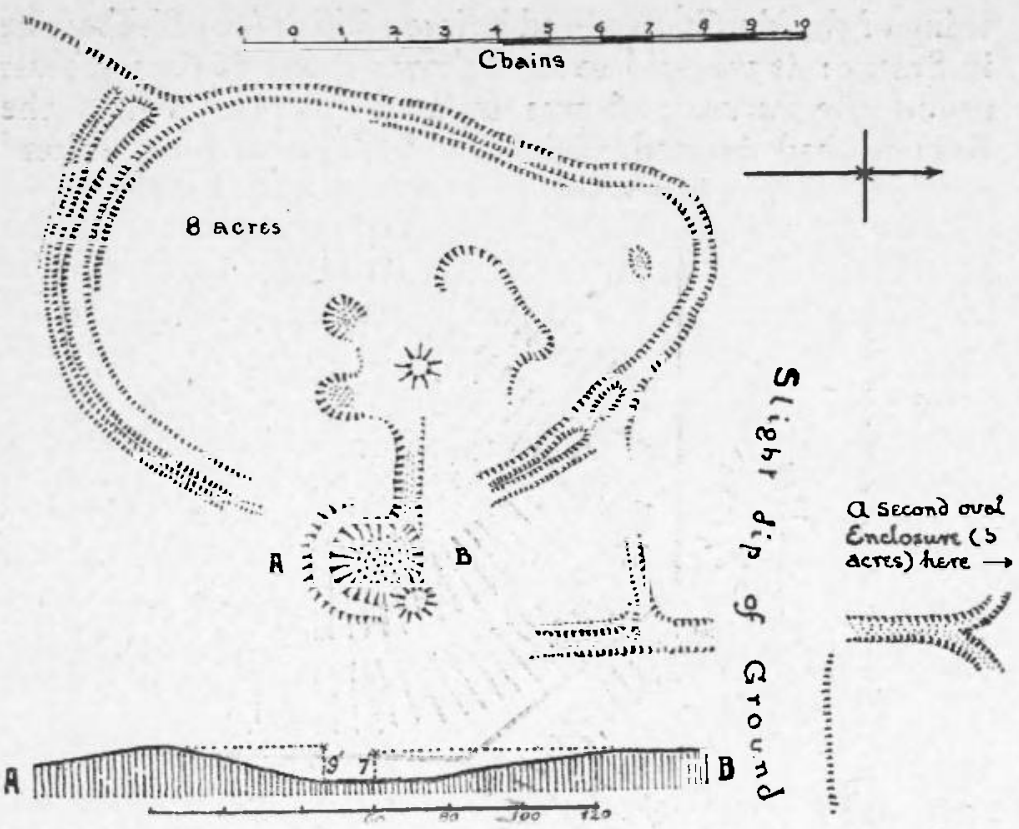

Fig. 3. SOUTH TARRANT HINTON DOWN: PRINCIPAL SETTLEMENT WITH CIRCUS AT GATE.

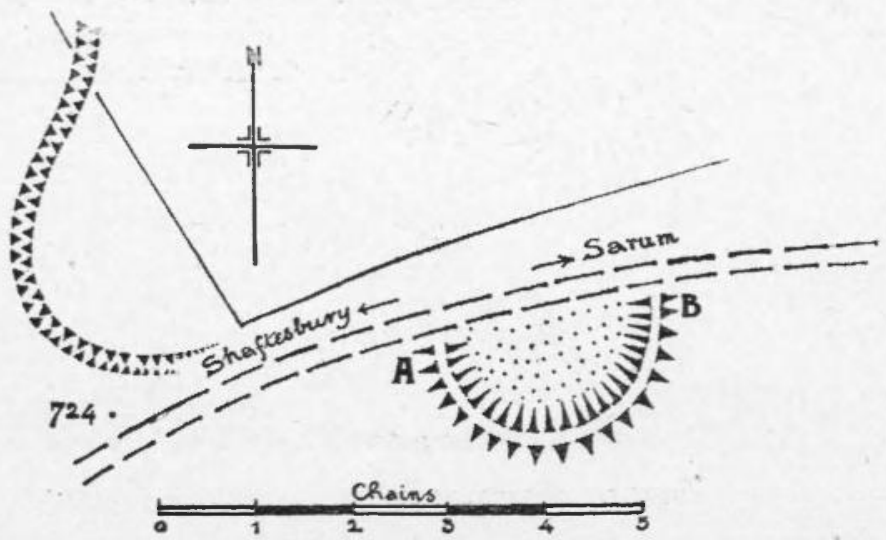

A m FIG. 4. SWALLOWCLIFFE DOWN, BETWEeN WHITESHEET AND CHISELBURY CAMPS. 
thing of the kind had existed before 1866 at (20) Fishbourne in Sussex : it was said to have shown traces of tiers of seats round the cavea, and was reputed 'a place where the Romans had burned their dead.' The present writer ${ }^{1}$

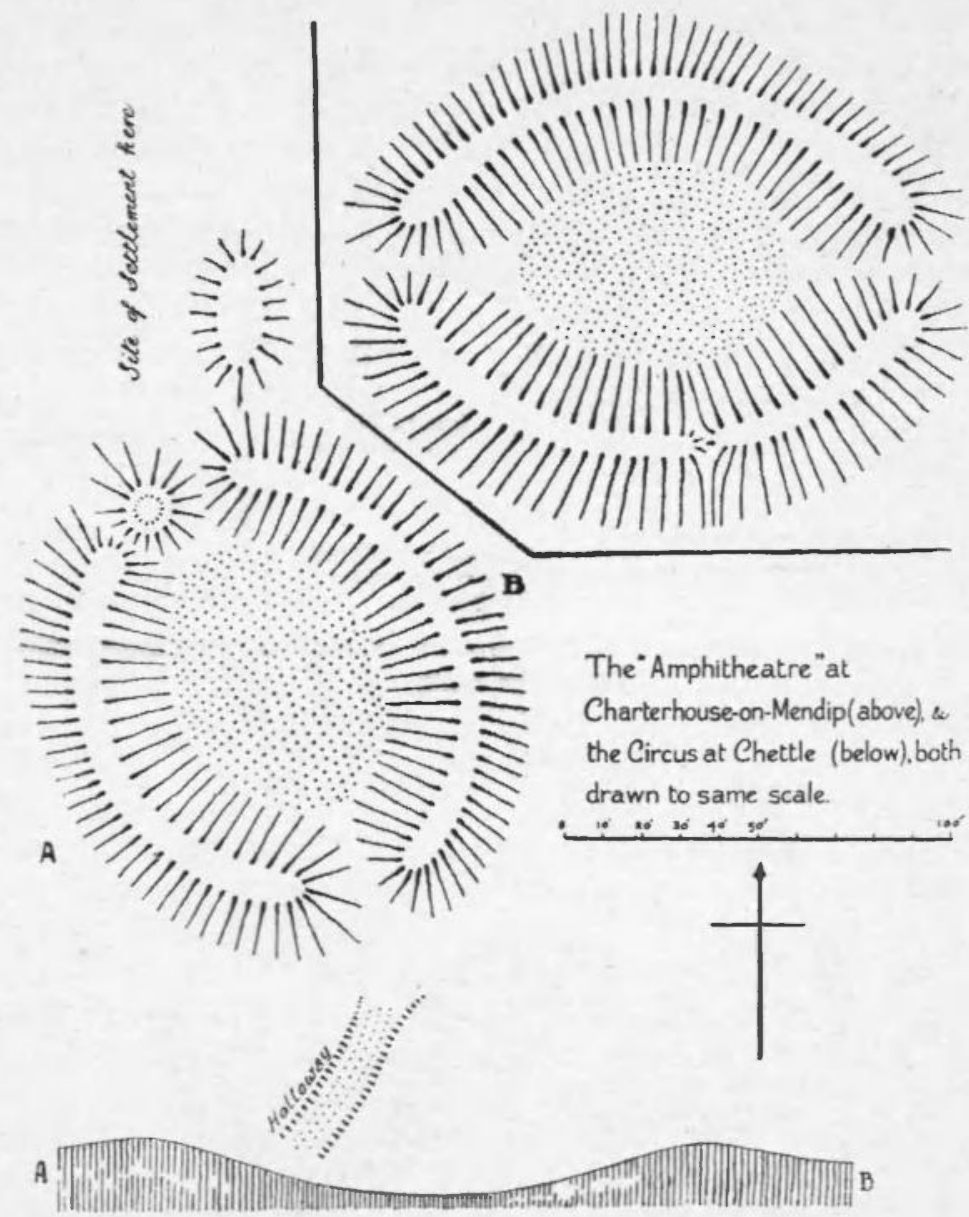

FIG. 5. CHARTERHOUSE-ON-MENDIP AND CHETTLE.

identified (2I) an example ( 87 by $72 \mathrm{ft}$.) on Buckland bank, in Falmer, Sussex (fig. 7). This was in 1916; and attention once drawn to the type, Dr. Eliot Curwen has already adduced seven others in the vicinity of Chanctonbury, of

${ }^{1}$ A Romen Circus on tbe Soutb Downs. (Brigbton Gazette, 27th March, 1918). 


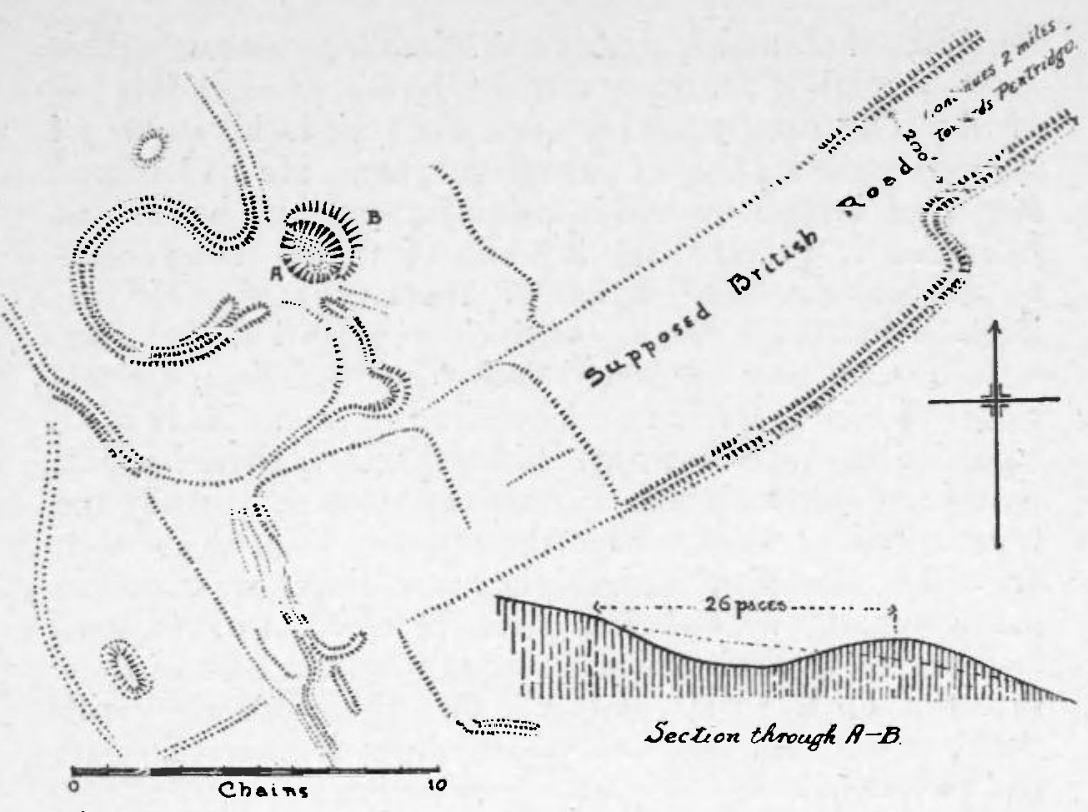

fig. 6. SETTLEMENT ON GUSSAGE DOWN SHOWING POSITION OF CIRCUS $\Lambda T$ GATEWAY.
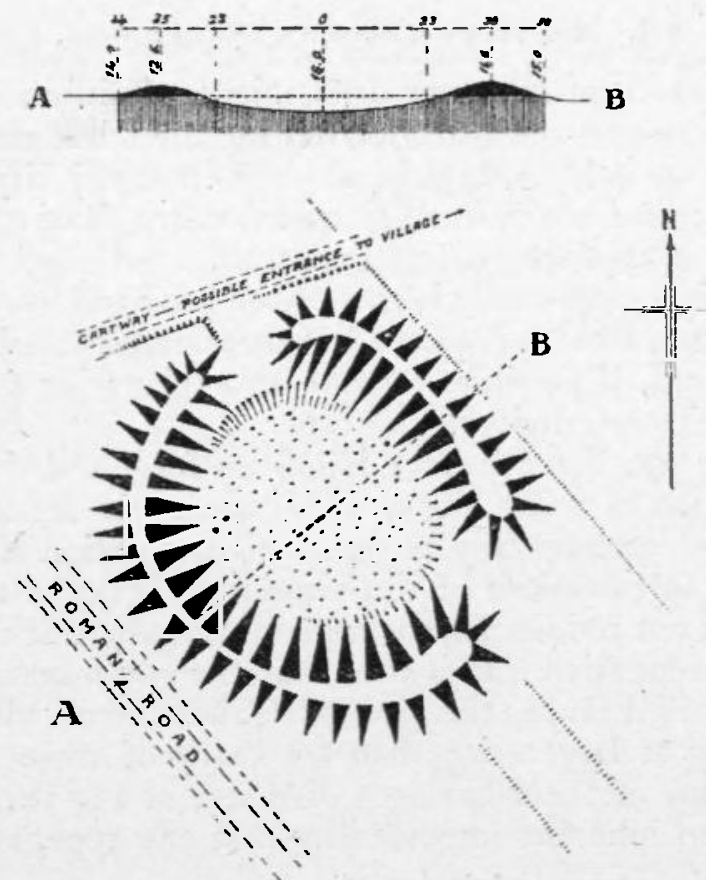

FIG. 7. CIRCUS ON BUCKLAND BANK IN FALMER, SUSSEX. 
Bowhill, of Arundel, and near Ditchling beacon. This makes a total of 28 , many of them in fair preservation.

Dr. Thurnam, touching upon the type in his survey of barrows ${ }^{1}$, denied its sepulchral purpose. He had indeed found an interment within one of them, but he had no hesitation in pronouncing it to be of a date "long subsequent' to the construction of the earthwork. He was inclined to accept the unconvincing suggestion that they were in some way connected with sepulchral rites, perhaps places of shelter for the workmen during the building of an adjacent barrow or barrows. Since that date there has not, that I am aware of, been any serious attempt to study the type. Various writers have therefore speculated about it at will. Cockpits, badger-pits, bull-rings, outposts or guard-houses, water-holes, sites of dwellings, pastoral enclosures-an explanation has been found in each of these in turn. Of late the 'pastoral' theory has prevailed with these, as with so many other earthworks of uncertain date and purpose.

\section{§3. PREVIOUS THEORIES INADEQUATE.}

Each of these many theories might possibly suffice to explain here and there an isolated instance, but no one of them can be held to explain all or even a majority of the instances; and as the works in question are all of one type, and that a type possessing remarkable and very definite characteristics, especially in the sunken floor and the absence of any fosses, what is required is a theory which shall satisfy all cases and, if possible, provide an explanation for these peculiar characteristics of the type.

It was not defensive, for it has no fosse and shows no smallest sign of palisading or other means of defence, nor is it found to have any recognizable connexion with the admitted fortifications of the associated settlement.

It was not residential, for it yields no sufficient traces of lengthy occupation. It is true that the mardelles or mares au diable of France, the sites of Gallo-Roman villas, are frequently of larger size than are many of these English works, some of them having a diameter of $140 \mathrm{ft}$., so that there is no inherent impossibility that the type, as Hoare

1 Arcbaeologia, rlii, p. 166. 
and Wilson and Thurnam fancied, might have been roofed. But the mardelles have yielded plentiful evidence of the timber used to roof them, whereas the English works show nothing of the kind; and while the English works are invariably provided with a vallum of remarkable proportions, Grenier is explicit that the mardelle as a rule has none at all. 1 And waiving other difficulties, it is not clear why a residence, and that from its size presumably the principal one of the whole settlement, should be so constantly placed in an unfortified and indefensible position outside the walls of the settlement to which it obviously belongs.

The last-named objection applies yet more forcibly to the 'pastoral' theory. A people who valued their cattle sufficiently to corral them at all would not place their corral outside the walls of the settlement and in the very teeth of any approaching danger. Moreover, an earthwork of this type, if ill designed to keep anything out of its arena, is even less well designed to keep anything in it. And, finally, a great number of them are much too small for the pr.rpose assumed.

All the evidence contradicts the theory of their sepulchral purpose, and for the 'water-hole' theory there is no basis whatever. ${ }^{2}$

There remain only those theories which connect the type with religion, with matters juridical, or with games. I hope to show that while none of these alternatives is wholly right, each is partially so. Ritual, justice, and various forms of sport had each and all their place therein, but none of these was the raison d'etre of the thing.

\section{§ 4. THE TYPE IDENTICAL WITH THAT OF THE ' AMPHITHEATRE.'}

In their essential features all are reproductions on a lesser scale of the type of work which on a large scale is

\footnotetext{
1 A. Grenier, Habitations Gauloises et Villes Romaines, p. 32.

2 There occur, however, pond-heads which bear more than a slight resemblance to the type, e.g. one in Water Lake Bottom, parish of Pentridge, Dorset. A pond-head, however, betrays its real character when the water-levels rise in winter, whereas the works
}

here under consideration commonly stand in places where there can never have been any springs. A favourite situation is on the brow of a slope, as at Berwick down by Tollard Royal, and at Chettle, but although commonly conspicuous, the position is never such as could properly be called defensible, and occasionally it is in the very bottom of a valley as at Arundel (plate II, B). 
admitted to be a Roman amphitheatre. The amphitheatres of Richborough ( 200 by I $66 \mathrm{ft}$.), Cirencester ( 148 by I $34 \mathrm{ft}$.), Silchester ( 158 by I $20 \mathrm{ft}$.) have long been recognised as such. Recent excavation has proved also those of Caerlleon and Caerwent ( 145 by I $21 \mathrm{ft}$.) and Maumbury Rings at
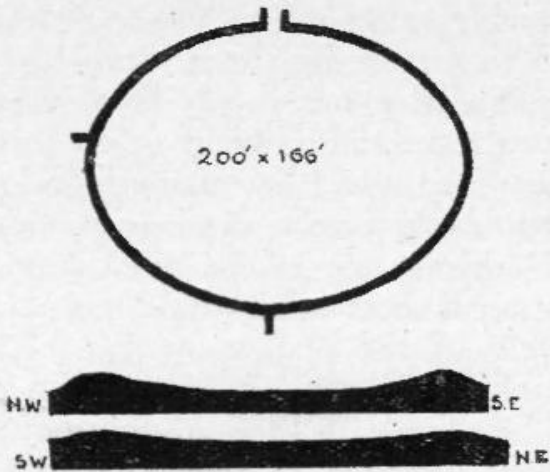

FIG. 8. AMPHITHEATRE AT RICHBOROUGH.
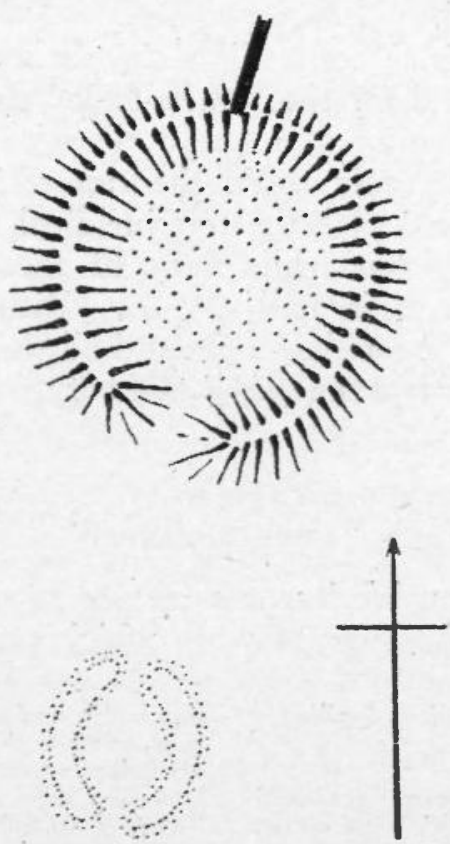

Fig. 9. AMPHITHEATRE AT SILChESTER (ARENA I 58 FEeT by I 20 FEET). present form shown above; below, the same as it was in 1872 , with both entrances (after J. G. Joyce, in Arcbaeologia, xlvi). 
Dorchester, and that at Charterhouse-on-Mendip ( 180 by I $46 \mathrm{ft}$.). The last-named (fig. 5) was grudgingly recognised, its relatively small size-the arena is 105 by $80 \mathrm{ft}$. - bringing it under suspicion; and for the same reason a possible amphitheatre at Borcovicium ${ }^{1}$ (fig. I2) on the Roman Wall ( 120 by $78 \mathrm{ft}$.) is still considered doubtful. Yet the still smaller one at Tomen-y-Mur, ${ }^{2}$ Merioneth, only $8 \mathrm{I} \mathrm{ft}$. in diameter, has been generally accepted as an amphitheatre. Is there any reason why that should be fixed as the minimum of size ? The usual reason to be advanced for such a limitation is that any smaller work would not be suitable for the purposes of an amphitheatre. Assuredly it would not, if the purpose were necessarily the display of chariot-races,

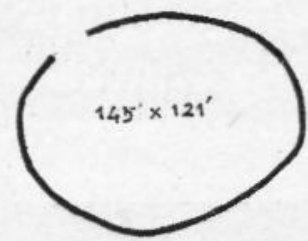

FIG. IO. AMPHITHEATRE AT CAERWENT.

naumachiae and venationes. But possibly these things were no part of their purpose at all, and certainly they were no necessary part.

For the moment, however, it is needful to establish the exact identity of type, larger or smaller. Excepting those of Llanidan (p. I I 7 ) and Tomen-y-Mur, all are oval. All have two entrances ${ }^{3}$ so far as can be determined. All have the depressed floor, with the solitary exception of that at Caerwent, ${ }^{4}$ which for other reasons is attributed by those who excavated it to a very late date and is capable of

${ }^{1}$ It is figured in J. Collingwood Bruce's Roman $W$ all. The plan here given is from field-notes of Eliot Curwen, M.D., who pronounces the work to be in all respects precisely like the circi of South Britain.

2 There is a poor woodcut of it in $A r c b$. Cambr. 5th ser. v, 267, with a long account by J. Romilly Allen.

3 That at Silchester had two entrances originally. Stukeley's plate shows the two, although his text contradicts the plate; for he says there was but one, and that the north-eastern, which to-day is blocked up. Joyce's plan in Arcbaeologia xlvi (1881) shows both entrances. The amphitheatre at Richborough was unusual in having the two main entrances at the extremities of the sborter axis; Roach Smith, Antiquities of Ricbborougb (1850), p. 162 .

1 Rowlands (Mona Antiqua, 1766) says that this was the case also at Llanidan in Anglesey. 


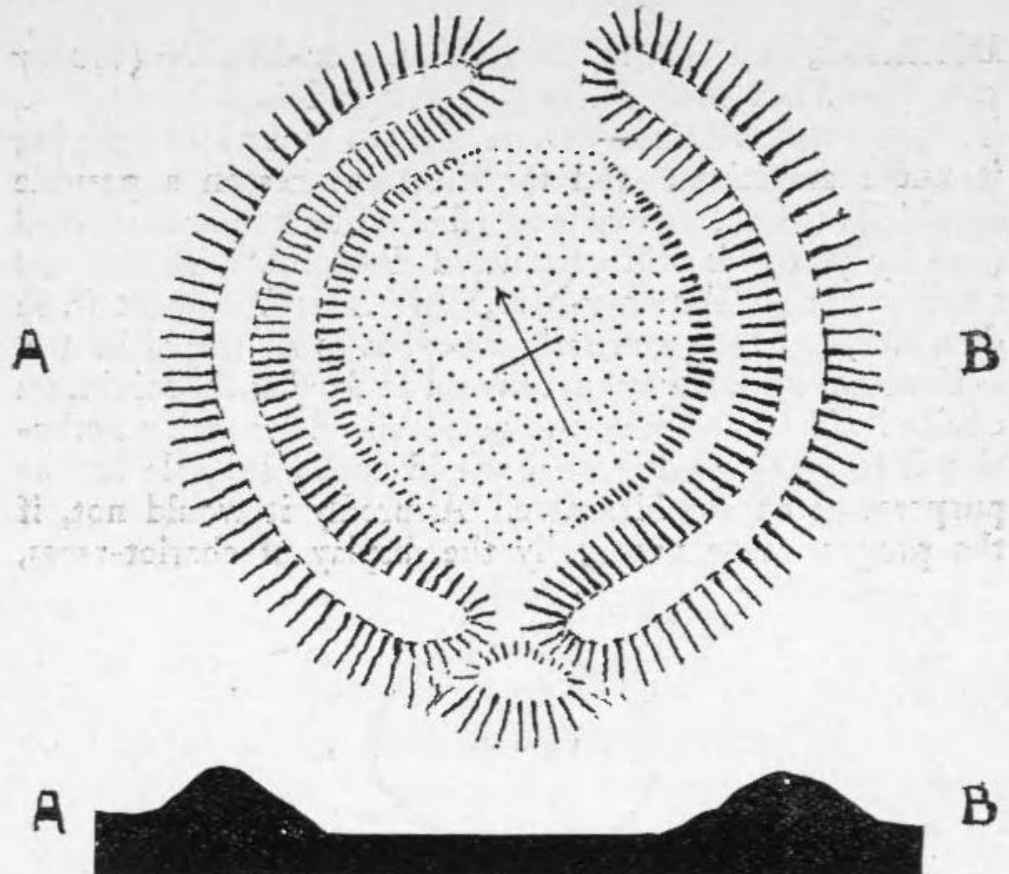

Fig. II. MAUMBURY RINGS, DORCHESTER (ARENA I92 FEET BY I 58 FEET).

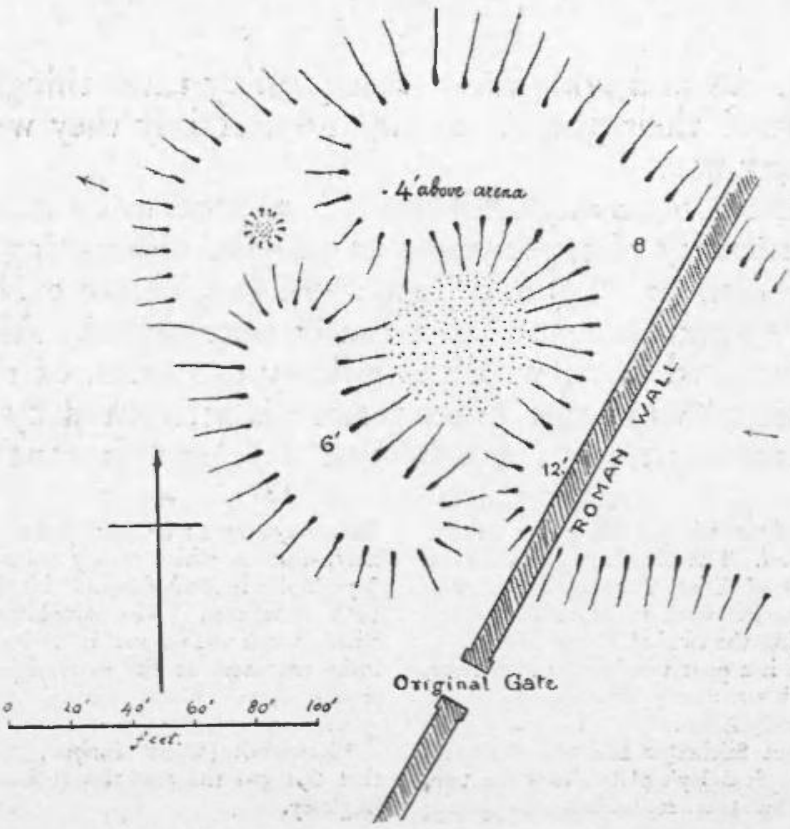

Fig. I2. Circus at borCovicium (housesteads), ON THE ROMAN WALl

(arrows show fall of ground; cavea 78 by 120 feet: the Roman station lies south-west at a distance of 130 yards). 
explanation. Even those which were in part constructed with masonry-Richborough, Caerlleon and Caerwenthad in the lapse of centuries assumed precisely the appearance of those constructed solely of earth, irrespective of their size: all showed the characteristic saucer-like cavea and the unduly wide vallum around it, without exterior fosse. From the immensity of Maumbury Rings downward to the tiny works at Gussage down and Woodcuts (Church barrow) they form an unbroken series, with no more noticeable difference than that some are geometrically circular, while some-the larger examples in particular-are not.

\section{§5. REAL 'CHARACTER AND PURPOSE OF THE ' CiRcUs.'}

If it were suggested that the diminutive $66 \mathrm{ft}$. work of Church barrow is an ' amphitheatre,' the suggestion would probably be met with ridicule. ${ }^{1}$ Most people derive their conception of an amphitheatre from such monuments as the Colosseum in Rome, or from its almost equally colossal copies at Capua and Verona, Nimes and Arles. But the very name of the Colosseum warns us that it was not a normal specimen of its kind, but something out of the common. It was in historical fact the last phase in an evolution of many centuries, and therefore, as was to be expected, little like its original. The original was to be found in every self-governing community of Latin Italy, and it was an oval or circular earthwork, with broad, low vallum and depressed floor, standing beside the road of approach to the gates of the town-exactly such a work as one may see to this day on the Romano-British sites in Cranborne Chase and elsewwere in that part of Britain which was more thoroughly Romanised. And the name of it was not ampbitheatrum, which is a loan-word from Greece and not older in Rome than circa 50 B.c., but circus, which is pure Latin and means primarily merely ' a ring.' 2

It is unfortunate that this word also, like ' amphitheatre,' has acquired in modern minds a connotation wholly foreign to its original meaning. Here again we are

\footnotetext{
I But it was so called by Rev. J. H. Austin in Arcbaeol. Fournal, xxiv $(1867), 167$, and Pitt-Rivers endorsed the name. Austin (loc. cit.) advanced an ingenious, but un-
}

satisfactory, explanation for the name of ' Church' barrow.

${ }^{2}$ Circus... omnis in gyrum ambitus. Cicero, Arat. 248. 
misled by the particular case and example of Rome. But Rome was not more truly Italy than Paris is France, and the Circus maximus as we think of it was as little like the typical circus as was the 'Flavian Circus' or Colosseum. Both were exceptional developments bred of the Roman mob's appetite for games and shows. Certain Italian archaeologists are satisfied that both are derived from one original, the little turf circus of the Italian country-towns; and that this itself was derived from a dead man's gravefrom a ring-barrow. ${ }^{1}$ Of the two, the stone-built ' amphitheatre' was, though later in time, in plan the more like its original, but in one respect the Circus maximus came nearer thereto, for it was a locus consecratus of singular dignity. Just without its gates stood the Ara maxima, and within it was the underground altar of Consus, ${ }^{2}$ on which men might look but thrice in the year. The amphitheatre or circus was as legitimately descended from the barrow as was the Greek theatre, ${ }^{3}$ and each came to be a peculiar architectural characteristic of the country which evolved it.

Ovid is at pains to tell us that the circus of Rome in the time of Romulus, its traditional first builder, was nothing but a turf-covered earthwork innocent of seats :

\section{Consedit populus gradibus de caespite factis}

(Ars Amand. i, 117).

Modified and enlarged through successive centuries, only in the days of the empire did it become the architectural marvel of popular conception. Amphitheatre Rome had none at all until 50 B.c., and that was of wood only, a temporary structure. ${ }^{4}$ Even in Tiberius's reign there was still a feeling that the provision of seats in such structures was an undesirable departure from old tradition. ${ }^{\mathbf{5}}$ And after Rome had jettisoned all such traditions and had

I So I am assured by Commendatore Giacomo Boni.

${ }^{2}$ It will follow that Consus was not originally a god of harvest or crops, but the god of death and of burial, a common signification of the allied verb condere : cf. Warde Fowler, Roman Festivals, p. 207. Precisely parallel are the English 'hell' and the verb (provincial) to beel, i.e. to cover up. Cf. billing for a 'rug, coverlet,' in frequent use in the Midlands. The proper meaning .of 'bell' is not 'place of torment,' but merely 'grave,' 'place of concealment': cf. A.S. belan and Lat. celare.

${ }^{3}$ Ridgeway, Origin of Tragedy (1910).

4 Built by C. Curio. The word means merely 'double theatre '; cf. á $\mu \phi \iota \dot{u} \pi \epsilon \lambda \lambda o \nu$, 'a double cup.' Curio's construction was actually two semicircular theatres revolving upon pivots so that they could be brought face to face, so forming a single circular amphitheatre.

5 Tacitus, Annales, iii, 72. 
completed the Colosseum (A.D. 79), the smaller Italian towns still went on in the old way with nothing more elaborate or luxurious than the original Romulean circus. Witness Juvenal (circa A.D. IOO) :

\section{Festa dierum}

Sacrorum herboso colitur si quando theatro Maiestas (Sat. iii, I73);

and the town's magistrates attended the occasional fettes therein, not in the uncomfortable pomp of the toga, but tunicati, ' in their shirt-sleeves.' The circus is here called by the imported Greek name of theatrum, and a century earlier Vergil had used the two terms as synonymousmediaque in valle theatri

Circus erat

(Aen. v, 288).

There are other passages in the classics which prove that such a circus was not an adventitious luxury, but a customary, nay necessary, adjunct of any self-governing community in the days when Rome was still republican. Thus Vitruvius (I, vii, I) remarks that the proper place for a temple (area) of Hercules ' in any self-governing community (civitas) which has no gymnasium and no amphitheatre, is near the circus (ad circum).' 1 The language is proof that, firstly, a circus and an amphitheatre were different things, and secondly, that while Vitruvius could quite well understand there being communities which had neither gymnasium nor amphitheatre, he could not conceive one which had no circus. Precisely the same is the implication of that clause of the Lex Ursonensis (44 B.C.) which enjoins that the aediles shall give ludi scenici 'either in the forum or in the circus.' 2 This law, be it remembered, was a legal document embodying the constitution of the municipium of Ursona (bodie Osuna). Such a constitution was confessedly a replica of that of any typical Latin municipium of the Italy of that date; and the law implies that such a municipium, if it did not attain to the dignity of a forum, would at any rate necessarily possess a circus. The passage further affords a hint of the real purpose of

1 Not in circo. There could no more be a temple of Hercules, or of any other divinity, in the circus, than there could be

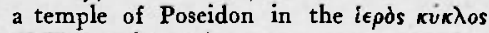
of Homer (p. I13).
${ }^{2}$ Bruns, Fontes Iuris Romani Antiqui, $7^{\text {th }}$ ed., $19 \circ 9$. 
such a circus, for it implies that such matters as were fittingly dealt with in the forum, if there was one, were properly dealt with in the circus if there was no forumthat the functions of forum and of circus were essentially the same. As the forum was simply the scene of all municipal activities, it follows that the circus had, or once had, exactly the same purpose. It was the municipal moot or thing. ${ }^{1}$

References to the circus in this capacity are very few, but one at any rate is forthcoming from Livy, who tells us (ix, 42) that in 305 в.c. the sixteen constituent peoples of the Hernican League assembled in moot (concilium) in the circus maritimus in the lands of the paramount people of Anagnia. Niebuhr (Hist. Rome, I838, ii, I6-37) surmised that this circus maritimus was probably the customary moot of the Hernican league, as that of the Latins was customarily at Ferentinum, albeit he made the usual mistake of supposing that it meant some vast arena like that of a Roman circus in the time of the early empire, ' a place only fitted for a concourse of thousands.' As there are the best of reasons for believing that the concilium of the Hernican league was a representative gathering of ten senators from each of the sixteen populi, or I6o councillors in all, a very small circus would suffice for the purpose; and nothing is known of the existence at so early a date as 305 в.c. of any circi in Italy constructed on the scale of Niebuhr's imagining. Even in Rome are traces of the same use: the Comitia Tributa, the civic assembly of the entire populus, met occasionally in the Circus Flaminius, which was not built until 2 I 2 в.c.

Dionysius of Halicarnassus, a contemporary of Vitruvius and Ovid, speaking of the same concilium of the Hernici, calls it by the Greek term of áyopá. ${ }^{2}$ We know from Homer $^{3}$ that the essential feature of an a $\alpha o \rho a^{\prime}$ in the Greece of his day (circa I000 B.c.), was a circle of stones which served as seats for the councillors. It was sacred ground

1 Tbing is usually held to be a Norse or Danish term, but the altars found at Borcovicium (see below, P. II6) prove that it was in use much earlier than those ethnic epithets would imply. The Saxon term moot, like the Greek term agora, denotes literally a 'meeting' or 'muster,' and secondarily the 'place of meeting.' The
Homeric patron-goddess of the nioot is Themis, and its primary purpose was $\delta\llcorner\kappa \boldsymbol{\eta}$, 'justice.' As Themis reappears in the Teutonic 'doom,' 'doom-ring,' so $\delta \iota \kappa \eta$ reappears in the term tbing.

${ }_{2}$ Dion. Hal. ii, 30 ; Niebuhr, op. cit. ii, $3^{1}$.

${ }^{3}$ See especially Iliad, xviii, 497-507; Odyssey, vi, 266, viii, 5 . 


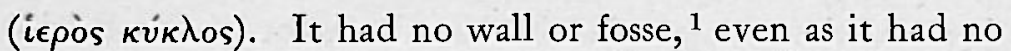
roof, because a moot was necessarily a public place and must therefore be accessible for all to see and hear what went on therein. It stood at the gates of the community, and the poet could not conceive a civilised community which had no ayopá. The crowning proof of the unqualified savagery of the Cyclopes is that "they have neither moots nor laws' -

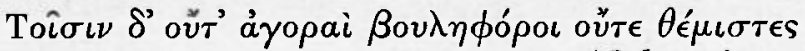

(Odyss. ix, I12).

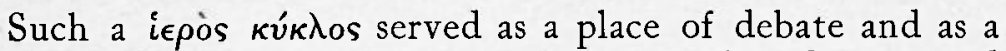
court of justice; as the scene of sports such as dancing and ball-play, boxing, wrestling and foot-races, and for poetical recitations; and near it stood also altars of various gods. ${ }^{2}$

\section{§6. THE MOOT DEVELOPED FROM A BARROW.}

But the 'sacred circle' itself originated in a sepulchral barrow, for the central feature of the agora of the Phaeacians was a 'goodly Posideum' ${ }^{3}$; and as king Alcinous of Phaeacia was grandson of Poseidon ${ }^{4}$ this central feature was merely the symbolical grave of his ancestor, the oecist of his city. It was a botbros, such as was to be seen in many, if not all, Greek theatres, e.g. those of Epidaurus and Piraeus.

The $\pi \rho v \tau \alpha \nu \epsilon i a$ (council-chambers and municipal buildings) of post-Homeric Greece were likewise of sepulchral origin, for they professed to be the burial-places or shrines of the oecists of their communities.

Sir W. Ridgeway has proved that the people of whom Homer wrote were not Greeks, but Celts who had occupied the Greek peninsula (Early Age of Greece, I901).

Sir John Rhys endorsed the view. that the moot of the British Celt was termed cruc. As this word, now written crug, is to this day the ordinary Welsh word for a round

1 This follows from Homer's express remark that the press of onlookers was kept back (Iliad, xviii, $5 \circ 3$ ) by heralds acting as police. To the present day an English lawcourt is a public place, a vestry is a public meeting.

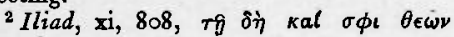
éteтé́xaro $\beta \omega \mu o l$.
${ }^{3}$ Odyssey, vi, 264. Liddell and Scott wrongly render this ' the temple of Poseidon.' It was no temple at all, for any such building would have filled up the arena and blocked the view and the hearing.

Ibid. vii, 56, 63 . 
barrow, the presumption is that the moot of the British Celt was likewise by origin sepulchral. It is a known fact that the chief moots of the Goidelic Celts of Ireland were usually barrows, ${ }^{1}$ and there is the strongest reason to believe that the moots of pagan Anglo-Saxons were likewise barrows. After their conversion to Christianity they made a new moot of the churchyard, and finally of the church itself. Until the sixteenth and seventeenth centuries the church and churchyard were the normal moots of every English tün, and there are still places in England where certain most characteristic municipal duties are performed within the church. ${ }^{2}$

There is therefore abundant analogy for the view that the Italian circus was itself developed from the round barrow, and this at once explains its most remarkable characteristics, viz. the oval or circular plan, the depressed floor, and the absence of any fosse; for while the plan was directly inherited from the barrow or cruc, its function as a public moot required that it should have no fosse, and the depressed floor was a ritual survival from the actual digging of a dead hero's grave. The very name circus is philologically identical with that of cruc, and both with the Teutonic brincg or ring ${ }^{3}$; and the term cruc itself had reference, not to the elevation, but to the circular plan, of the thing so called.

That the mixed people of whom history speaks as Romans contained a very large element of Celtic blood, is generally admitted. That another of its component elements came into Italy from Greece at a date within, or very shortly after, the Homeric age, is the persistent tradition of Italy itself, and is strongly maintained by modern authorities. These are, therefore, two ways of explaining how it might happen that the moots of the Old Latins and of Homer's Celtic Acheans were so much alike in form. Both were circular and both were sacred. Most striking of all is the parallelism between the Homeric

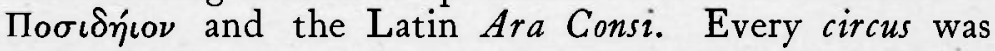

\footnotetext{
${ }^{1}$ O' Curry's editor (Manners and Customs of tbe Irisb, i, p. cclv) says that the Irish Aenacbs or fairs were invariably held at burial-places.

${ }^{2}$ As, for example, the annual election of the mayor of Brightlingsea, Essex, within the parish church.
}

s Dialect form, krink (Low Dutch.) The English ' rick,' meaning a round heap of hay or corn, is identical. The same heap, if of a rectangular shape, is called a 'stack.' 


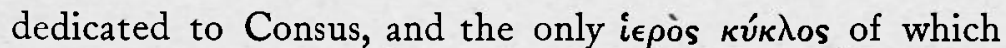
we are told the dedication was dedicated to Poseidon; wherein is the possible explanation of the fact that Roman writers, confessedly ignorant of the true meaning of Consus, brought themselves at last to believe that it was merely a title of Neptunus Equester, albeit Dionysius of Halicarnassus (ii, 3I) explicitly says that 'no man ever heard' of underground altars being erected to that god. Even the bad guessing of popular etymology, which tried to connect Consus with consilium, ${ }^{1}$ contains an implicit admission that the circus was primarily a place of council; and in Homer $\beta o v \lambda \eta$ is used as synonymous with àyopá. ${ }^{2}$ Dionysius adds that he had heard that Consus was in reality a god who 'guides and guards dark counsels,' and Plutarch says the same (Romulus xiv).

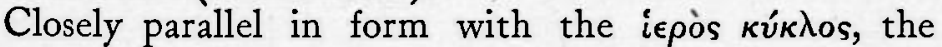
circus of the Latins was, it seems, originally identical in purpose. It was the 'municipal building' of its community, the 'town-hall,' the single scene of all communal business, whether deliberative, judicial, religious, or recreative. In historical Rome differentiation-evolution, that is-had gone so far that each of these purposes was provided with a special locus of its own, the circus surviving, in greatly modified form, as a recreative moot only, and specifically a race-course. ${ }^{3}$

\section{\$7. THE CIRCUS PRIMARILY A MOOT.}

The irresistible inference is that the peculiar British earthworks here under discussion are nothing more or less than the municipal buildings of the adjoining settlements, and that they were constructed in lieu of the older native moots under Italian influence in days subsequent to the Roman conquest. That this was so in such cases as those of Richborough, Cirencester, and Caerlleon, hardly requires

\footnotetext{
1 Tertullian (de Spectaculis 8) asserts (c. 200 A.D.) that the Ara Consi bore an inscription Consus consilio Mars duello ... POTENTES. The inscription may have been a clumsy forgery, but it must have refiected a popular belief.

2 For example see Iliad, i, 490-I, as com,pared with Iliad, ii, 202.
}

\footnotetext{
${ }^{3}$ Under the Republic, at any rate, gladiatorial games were not permitted in the circus. Bloodshed and the wearing of arms had no place in the civil moot, and even the passing through the circus of a condemned slave on the way to his execution was an outrage which the gods visited upon its authors. Vide Cicero, de Divin. i, 26.
} 
to be urged. It was proved to be so by the excavation of those of Charterhouse-on-Mendip ${ }^{1}$ and of Woodcuts (Church barrow). ${ }^{2}$ Analogy suggests that it is true also of the large number of similar works previously enumeratedtrue indeed of all works of the particular type.

Pitt-Rivers not only established the post-Conquest date of the circus of Church barrow, ${ }^{3}$ but he showed further that it was a reconstruction of something else-a barrow, so he surmised-of sacrosanct character. Undoubtedly of something that had the form of a barrow, but possibly no actual barrow, but a cruc, i.e. the earlier barrow-like moot of the community. That the community would deliberately destroy the actual burial-place of any of its forbears is hardly thinkable; that it would remodel what was after all but a symbolical barrow is likely enough. Here, at any rate, is the circus which was built to be the moot of the community in post-Conquest days. That community must have had a moot before. Where was that earlier moot ? The community being the same, and remaining upon the same spot, presumably its moot likewise remained on the same spot; and that is precisely where Pitt-Rivers from independent evidence inferred that there had existed some earlier work of a sacrosanct character.

That every moot was sacrosanct, a locus consecratus, is a certainty. It was so in Homer's time as in the days of classical Greece. It was so in Rome. It was so in the earliest Welsh laws and equally so in Saxon days, when those who were journeying to and from the moot, a fortiori all who were present in the moot, were under the guarantee of a 'truce of God.' Even those cives Tuibanti (recruits from Twente in Over-Yssel) who formed part of the garrison of Borcovicium had their thing and dedicated to the god thereof two altars, still to be seen in the museum at Chesters, bearing the barbaric legend Marti Thingso

\footnotetext{
1 Proc. Somerset Arcb. and N.H. Soc. Iv (1909), pt. ii, pp. 1 18-137.

2 Pitt-Rivers, Excavations, i, pp. 24, 124.

${ }^{3} \mathrm{He}$ found Samian ware within the body of the vallum.

These altars were found in 1882 on Chapel hill, the site of the Mithraic temple of Borcovicium. See Arcb. Aeliana, 2nd. ser. $x, 148-172$. Whether the tbing in question was identical with the circus of Borcovicium
}

already mentioned (p. Io7) may be matter of argument, but common sense suggests that it was so. The peculiar position of that circus (outside the Wall) suggests, however, that it was there before the Wall was built, and ergo before the cives Tuibanti were drafted thither. It will be noticed that they style themselves cives, and as has been shown, a moot of some sort was essential to every civitas. 
'Woden the Councillor,' the equivalent of the Roman Consus and of the Athenian Zev̀s 'A yopaios.

Seats, as has been said, were hardly to be looked for in the moots of small communities, but there is evidence that they were occasionally provided by making steps, the gradus of Ovid, in the gentle interior slope of the vallum; and the peculiar form of this vallum, with its slight elevation and exaggerated inward spread, was expressly designed to provide sitting accommodation for those who assisted at the moot.

Lower recorded the tradition that there had been such in the circus at Fishbourne. Warne says the same of that which once stood on Broad Mayne down. Tradition declares there were once seats in that of Cirencester, and traces of the original stone seating are recorded to have existed in that of Llanidan in Anglesey. ${ }^{1}$ If any one should object that, if the generality of these works were verily produced under Roman influence, they ought to show some remains of masonry, the answer is that, as Colt Hoare and Pitt-Rivers remarked, masonry in any shape is of the rarest occurrence in these country-towns of Roman Britain. Professor Sir P. Vinogradoff (Growth of the Manor, pp. 37, 38) appears to hold the same view.

\section{\$. THE QUESTION OF SIZE.}

A more pertinent objection might be raised upon the score of their small size. A circus like that of Church barrow or Gussage, let alone that at Buzbury which Warne pronounced to be "little more than half the size of Church barrow,' might be thought to be too small for the purposes suggested. But if one will put aside all fancies about horseracing and such spacious forms of entertainment, and bear strictly in mind that the prime purpose of a moot was debate, the difficulty vanishes. A circus no bigger than that of Church barrow would easily accommodate 500 persons; and be it remembered that we have no means of knowing how large a community must be before it could hope to command a part in the control of its local affairs. 
We do know from the Spanish Lex Ursonensis (44 B.c.) and from the Leges Malacitana and Salpensana (A.D. 96) that such a community might be very small.

During the late war there was constructed (1916) in the camp at Shoreham, Sussex, an ' amphitheatre' for boxingmatches and other such displays. Its plan (fig. 14) was that of a horse-shoe magnet, the radius of the semicircular part of the arena being $3 \mathrm{I} \mathrm{ft.,} \mathrm{and} \mathrm{the} \mathrm{length} \mathrm{of} \mathrm{the}$ tangential 'legs' respectively $5^{8}$ and $62 \mathrm{ft}$., giving a podium of the total length of $215 \mathrm{ft}$. or thereabouts. From this podium there sloped up nine tiers of seats, with some four extra tiers round the head of the arena, where the natural rise of the hill-side allowed it. The seating accommodation thus provided was found to be sufficient for 2,000 men. ${ }^{1}$

A circular work having an arena with a diameter of $80 \mathrm{ft}$. and a cavea with diameter of $\mathrm{I} 20 \mathrm{ft}$., and two entrances each $\mathrm{I}$ o ft. wide at the floor, would amply accommodate the same number of persons all seated. A similar work with a cavea of but $66 \mathrm{ft}$. diameter-the actual dimension of Church barrow-would accommodate 600 persons, if the arena were $40 \mathrm{ft}$. in diameter, many more if the arena were smaller. It would therefore have been amply large enough for any population which could have gathered within the narrow limits of the 'village' of Woodcuts; and a circus of mean size, i.e. with diameter of $70-80 \mathrm{ft}$., might have seating-space for between 800 and I, I oo persons. If the assembly stood, the number might well be half as large again. There can therefore be no objection to $\mathrm{my}$ interpretation of these works on the score of the small size of many of them.

\section{THE 'FRYING PAN,' HAM HILL, AND PUGH DEAN, ARUNDEL.}

This view provides at last a reasonable explanation of the analogous work (plate II A and fig. I3) which occupies an angle of the vallum surrounding the immense pre-Roman camp of Ham Hill, Somerset. It is perfectly circular, with 


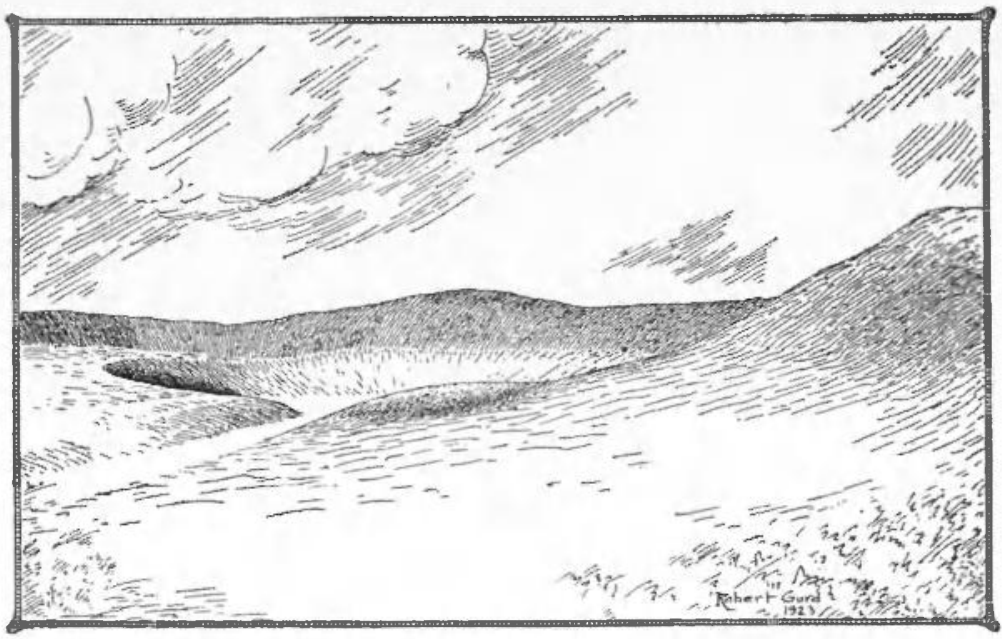

A.-THE "FRYING-PAN," HAM HILL, STOKE-SUb-HAMDON, SOMERSET. (Drawn from a pbolograpb taken by Rev. $W$. Budgen.)

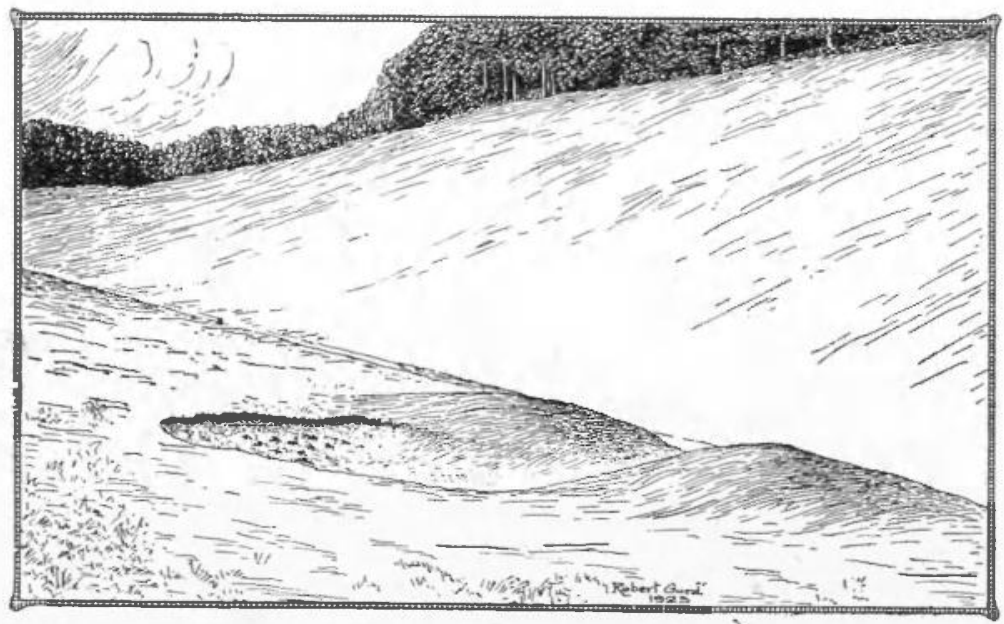

B.-THEATRAL CIRCUS IN PUGH DEAN, ARUNDEL PARK : VIEW FROM SOUTH-WEST. (Drawn from pbotograpbs.) 
diameter of $104 \mathrm{ft}$. over all. The floor, slightly concave, and covered with perfect turf, has a diameter of $64 \mathrm{ft}$. only, from which the sides rise in a regular slope to a height of
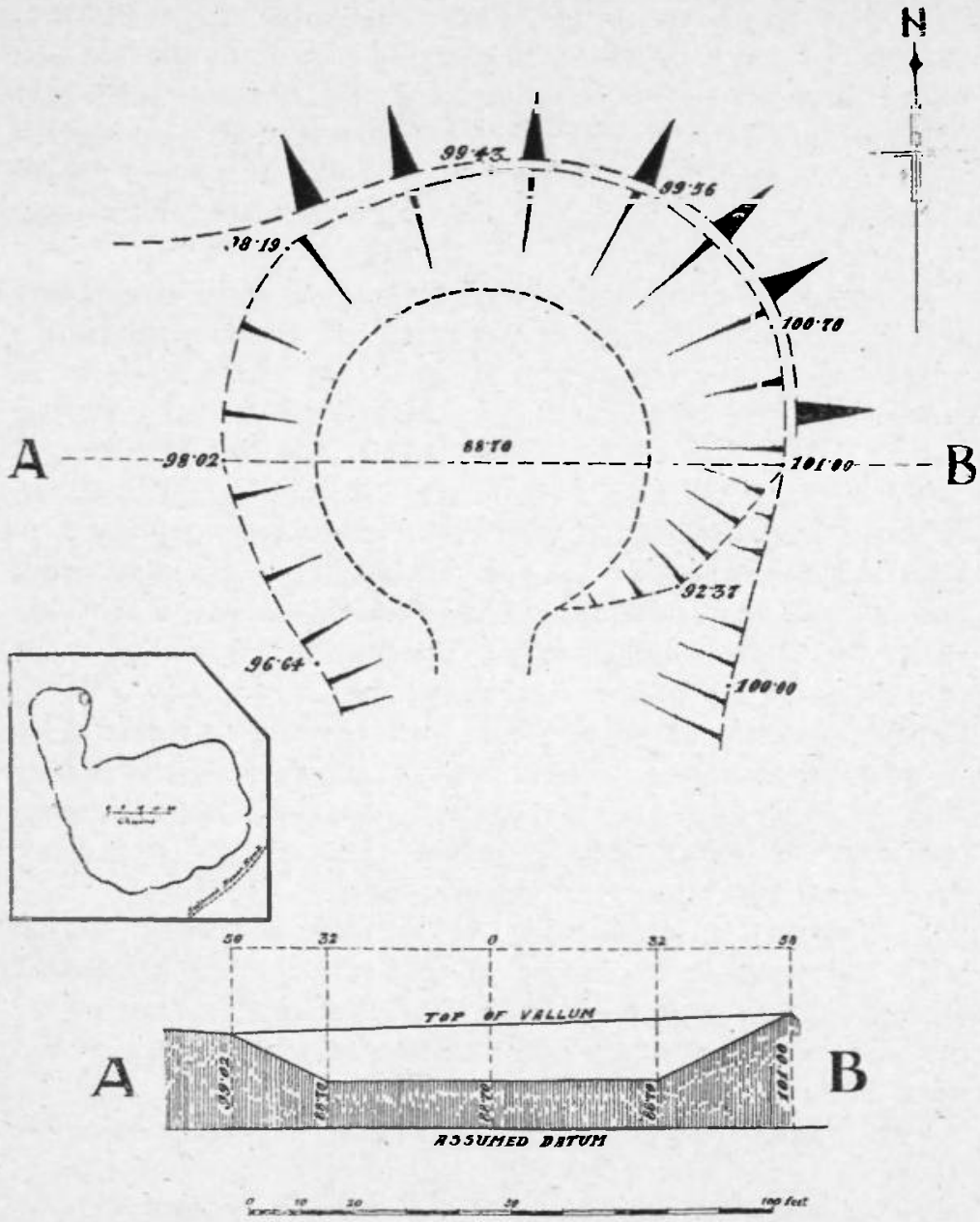

Fig. 13. CIRCUS AT HAM HILL, STOKE-SUb-HAMDON, KNOWN AS THE "FRYING PAN." INSET, PLAN OF haM HILL CAMP, THE CiRCUS AT N.E. POINT.

$10 \mathrm{ft}$. on the west, $12 \mathrm{ft}$. on the east; the length of this slope being $20 \mathrm{ft}$. on the west, and as much as $28 \mathrm{ft}$. on the eastern side. ${ }^{1}$ There is only one entrance, on the south

1 It is an odd coincidence that the angle of this slope is to all intents identical in the

cases of the 'Frying Pan' and the Shoreham military amphitheatre. 
side, and the plan of the whole has gained for it the descriptive name of the 'Frying Pan.' Tentative excavation of the floor has produced nothing but scraps of RomanoBritish pottery; and, unable to provide another explanation, antiquaries have usually written it down as medieval, and have supposed it was intended for the Shrove-tide sport of cock-fighting. ${ }^{1}$ The sufficient objection to this theory is its size. As a rule the sport of cock-fighting asked for no such apparatus whatever, let alone a pit of these dimensions, very considerably larger than the average circus.

Now numberless finds have made it certain that there was a Romano-British community of some importance within this camp, and the majority of these finds have come from the immediate neighbourhood of the 'Frying Pan.' There can be no doubt that the community stood close by the 'Frying Pan,' that this too is a RomanoBritish work, and that it was the circus of that community. Like the other circi it has the sunken floor, it has no fosse, and it has the broad and gently-sloping vallum to provide space for those who attended the moot. It differs from other circi already mentioned in one point only; viz. in having but one entrance, ${ }^{2}$ and this is instantly explained by its peculiar situation, which did not allow of the construction of a second. This peculiar situation has, however, preserved it to all intents intact through the centuries. As it has never been ploughed over, it is probably the most perfect 'amphitheatre' to be seen in this country, ${ }^{3}$ with the possible exception of that at Cheney Longville. In fig. I4 is shown the plan of the 'Frying Pan' with that of the Shoreham military amphitheatre superimposed upon it. ${ }^{4}$

In Pugh Dean, in Arundel park, ${ }^{5}$ is an earthwork (plate II B, and fig. I5) which can hardly be other than a circus, albeit superficially quite different from those above

I The same name is found attaching to other circular works, where is no suggestion of cock-fights and Shrove-tide; e.g. the fine $100 \mathrm{ft}$. ring barrow at Blackheath near Todmorden.

2 But the circus on Tarrant Hinton down (fig. 2), and that on South Tarrant Hinton down (fig. 3), may have been of the same plan.

'For details of the 'Frying-Pan' see Arcbaeologia, xxi, 40; xxxi, 320; and
St. George Gray in Proc. Soc. Antiq. Lond. $x x i, 128$. The measurements given are those determined by a qualified surveyor in 1917 , through the kind offices of Dr. Hensleigh Walter.

"The dimensions of the "Frying Pan" are almost identical with those of the Greek theatre of Delos (Blouet, Expedition de Moree).

${ }^{5}$ It is some 200 yards due east of the Duchess's Lodge on the London road. 
described. It lies at the actual foot of the steep slope forming the western side of the valley (O.D. c. $300 \mathrm{ft}$.), scooped out of the hill-side in precisely the fashion of a typical Greek

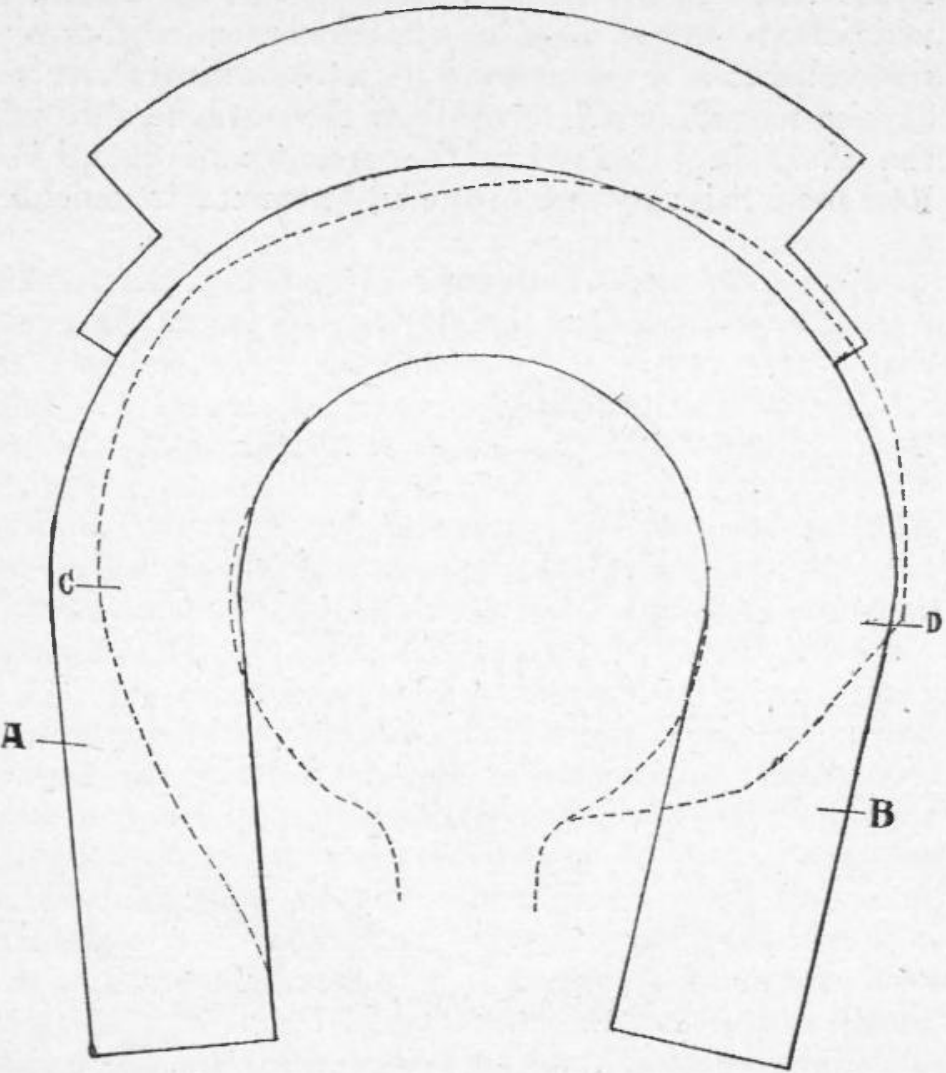

A

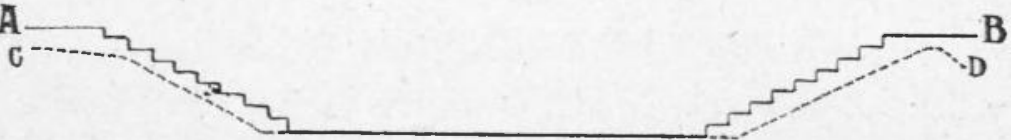

FIG. I4. MILITARY ARENA AT SHOREHAM (I9I6) SUPERIMPOSED ON THE CIRCUS AT HAM HILL. BOTH IN PLAN AND IN SECTION (SHOREHAM SOLID, HAM HILL BROKEN LINES. WIDTH ON LINE A-B $=$ IO4 FEET).

theatre, with a mean diameter of $50 \mathrm{ft}$. only. ${ }^{1}$ The deblai from the sunken cavea has been methodically thrown outward so as to build two slightly curved mounds enclosing

1 The work is slightly elliptical, the shorter diameter, as in the case of Gaer Ddu, being that on which lies the entrance. 
the lower (E.) side, leaving a single entrance, 5-6 ft. wide at the floor, which opens direct upon the hard green trackway up the valley towards Whiteways Lodge. So narrow is the valley here that this trackway, not more than $8 \mathrm{ft}$. wide, fills its entire floor, and the eastern side rising with a slope almost as steep as that of the western side, it is not easy to see where can have stood the settlement to which the circus belonged; but the presence of quantities of Romano-British pottery in the rabbit-scratchings along the

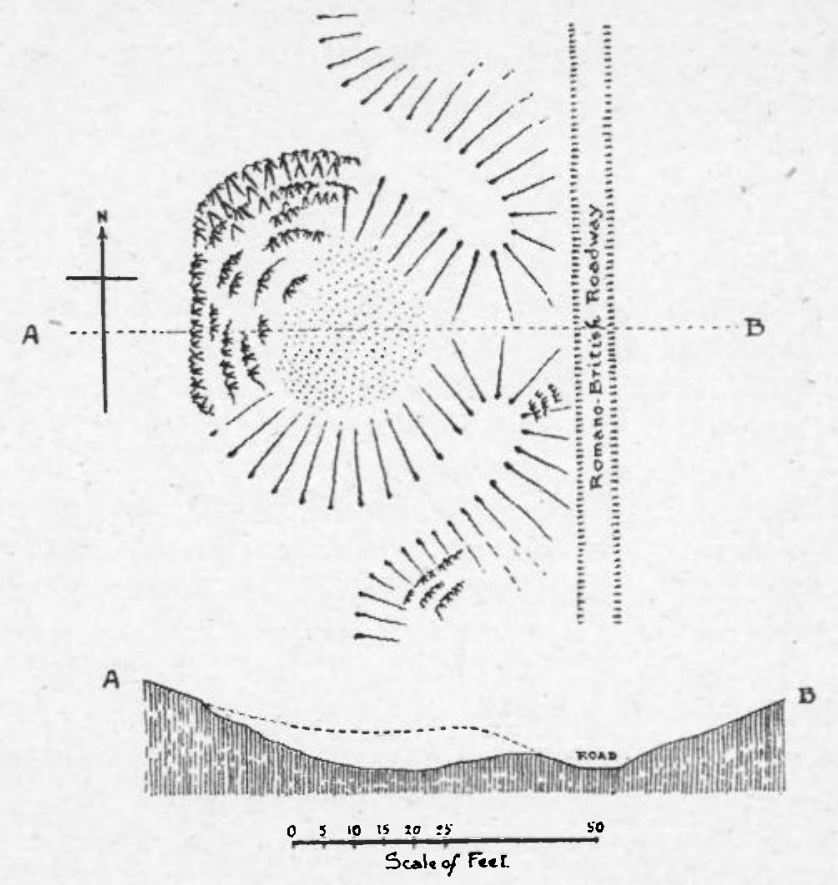

FIG. 15. CIRCUS IN PUGH DEAN, ARUNDEL PARK.

valley to the south, as well as on the surface of the circus itself, and over the whole of the plateau eastward for most of a mile, is proof that a settlement stood here, apart from the further fact that the roadway, at a point 150 yards north, assumes the characteristic form of a Roman terraceway, ${ }^{1}$ broadening as it rises to as much as $20 \mathrm{ft}$. The

\footnotetext{
1 See on this matter the writer's article in Arcb. Fournal, lxxii. The different construction of the hardway and the terrace is indicated by the rabbits: they have burrowed freely into the made portion of
}

the bed of the terrace and on both sides of the road itself, whereas they have rarely or never broken the surface of the hardway. See also Sussex Arcb. Coll., lxiii (rg22), p. 72. 
vallum of this example is from the nature of the case confined to the lower (eastern) side of the work, and rises 6-7 feet above the trackway. The activities of rabbits and ferreters have so mauled the actual floor that it is not possible to say what was the original depth of the cavea, which was, however, very obviously sunk. It cannot well have been less than 5-6 ft. below the periphery. Here, then, is another type of circus, and of peculiar interest in that it shows how the moot-circle might even in far-away Britain assume a form and construction identical with that of the Greek theatre, which was itself another offspring of the same ancient parent, the worship of the dead. 1

§ IO. CAERWENT, CHENEY LONGVILLE, Y GAER DDU.

The excavators of the amphitheatre at Caerwent (fig. Io) came to the conclusion that this was of late construction : it was built within the walls of the city, a number of older buildings having been pulled down to make room for it ; it lacked the symmetry of earlier works of its kind; the masonry of the retaining walls was cheap and weak; and the floor of the arena was not sunk. ${ }^{2}$ It belongs to a time when the ritual significance of the sunken floor was, if not forgotten, at any rate ignored. ${ }^{3}$ There is extant part of an inscription which proves that this city was a selfgoverning populus administered by an ordo or senate. ${ }^{4}$

In certain other cases the sinking of the floor is present, though not at first sight apparent. Thus at Cheney Longville (plate I and fig. I6), two miles north of Craven Arms in Shropshire, and less than a mile from the Shropshire Watling Street, the Roman road from Uriconium to Bravinium (Leintwardine), is a beautiful example, of which it was written in 1909 that it 'might almost pass for a Roman amphitheatre. ${ }^{5}$ Its diameter is $I 20 \mathrm{ft}$., it is perfectly

\footnotetext{
${ }^{1}$ Ridgeway, Origin of Tragedy. On the gentle southward slope overlooking Eastwick bottom in Patcham, two miles north of Brighton, a locality strewn with the indicia of a dense Romano-British populationlynchets, roadways of Roman and Celtic types, and pottery in profusion-is what may be another example of this type of circus (diam. $40 \mathrm{ft}$.).
}

2 Arcbaeologia, lix (1905).

${ }^{3}$ A similar development is noticeable in one or two Greek theatres, e.g. in that of Mantinea.

- Dr. Haverfield in Atbenaeum, 26 Sept. 1903; Vinogradoff (Growtb of Manor, p. 103).

V.C.H. Sbropsbire, i, $3^{80 .}$ 

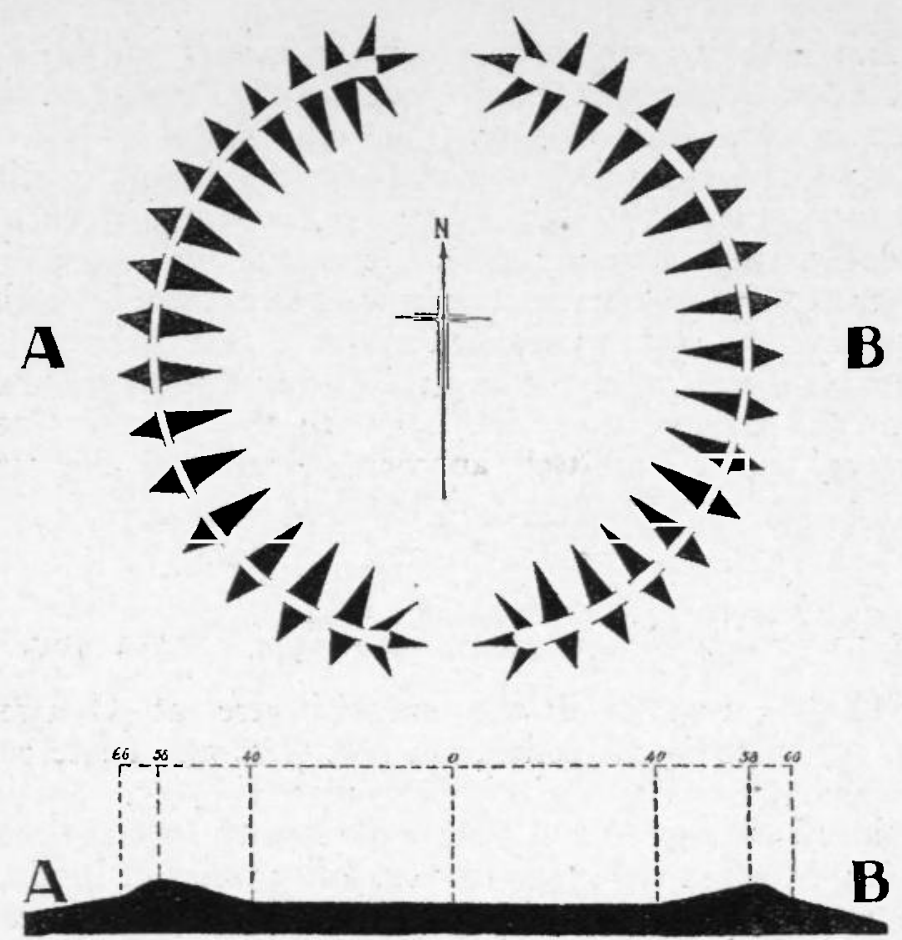

FiG. 16. CiRCUS AT CHENEY LONGVILLE, NEAR CRAVEN ARMS, SALOP, KNOWN AS "THE GREEN."

A mile 1. West runs

a Roman Road from Castell Collen to Builh, dincction viuin-x-üunm.

The hill palls sticeply to West, on to North.

Soil clay. Jhe graund has been seamed wath drainage trachis in recent years.

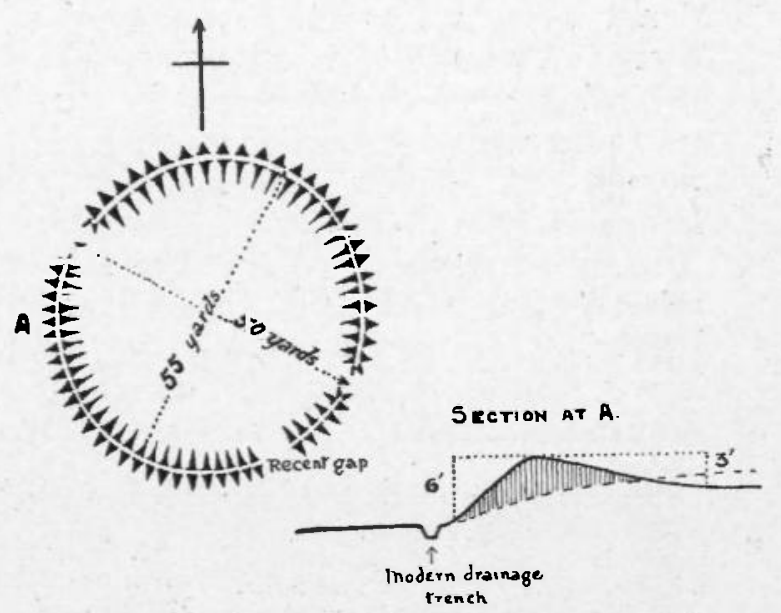

FIG. 17. CIRCUS KNOWN AS Y GAER DDU, HOWEY, NEAR LLANDRINDOD WELIS. 
symmetrical, and it has the customary broad low vallum; but the arena is higher than the natural surface of the ground without and nowhere falls below the 'sill' of the two entrance-ways. Thus at first sight this seems to be another case in which there is no sinking of the floor, but it is not so in reality; for the work is constructed upon a slight, but measurable, knoll, the summit of which has been pared off and used to form the vallum.

Exactly parallel is the work known as $r$ Gaer $D d u$ (fig. 17), 'The Black Fort,' at Howey, one mile south of Llandrindod Wells in Radnorshire, and a short distance east of the Roman road from Castell Collen (? Magos) towards Builth. ${ }^{1}$ Here the ringwork is placed upon an almost imperceptible knap on the brow of a westward slope, the plan being slightly oval with a mean diameter of some I $70 \mathrm{ft}$., and the flat floor on a dead level with the two entrances. ${ }^{2}$

The reason for this particular method of construction is perfectly obvious, and well illustrates the practical good sense of the Roman engineer, whose motto was ever the Horatian

\section{mibi res, non me rebus subiungere conor.}

A depressed floor such as that of the circi in Cranborne Chase and in the South Downs was practicable on the chalk, ${ }^{3}$ but impracticable on soils more retentive of water, on clay for example. Here it was necessary so to construct the circus that there should be automatic means of draining the arena; and both at Cheney Longville and at Howey the water escaped from the floor through the entranceways.

1 Described as long ago as 1814 by T. Price (Arcbaeologia, xvii, I 7 I) as 'a Roman amphitheatre, if it be not a Druidical something.' In Inventory Radnorsbire, nos. 317, 318 , it is wrongly described as having a fosse. There is no fosse other than a modern drainage-trench similar to others with which the area and surrounding soil, a heavy clay, have been seamed.

${ }^{2}$ As at Richborough, these are at the ends of the minor axis.
${ }^{3}$ There were, however, limitations even on the chalk. A small circus could be relied upon to get rid of its own drainage-water, but a big one might present difficulties. Thus the immense area at Maumbury, which was sunk to a depth of Io ft., and had, moreover, to get rid of the water collected in a catchment-basin some fifteen times larger than the mean, was provided with a complete system of blind-drains or "soakaways,' which appear to have been mistaken for "prehistoric' shafts. 


\section{§II. 'CIRCI' CONFUSED WITH 'CAMPS.'}

As the name of the work at Howey declares, it has hitherto passed commonly as a ' camp,' an attribution which is at once refuted by the character of its enceinte. It is probable that a large number of similar so-called ' camps'
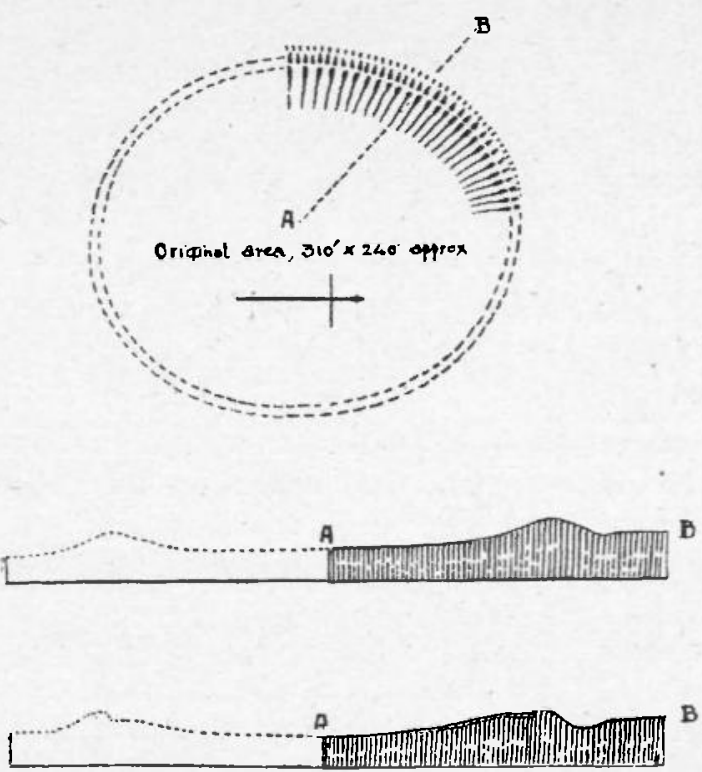

FIG. I8. CiRCUS ON MOOTHILL FARM, CASTLESTEAD, YORKS.

The upper section A-B was taken before, and the lower after, excavation.

will likewise turn out to have been moots or circi. At least one other example is forthcoming at Castlestead Rings, near Cullingworth, Yorks., where there remains (fig. I 8) but the quarter of the enceinte of a large oval enclosure. ${ }^{1}$ Digging trenches across this, Dr. Francis Villy proved that it had been constructed after the plan of a modern hippodrome, the outer edge of the floor 'ramped up' to a terrace $3 \mathrm{ft}$. wide, which ran round the enclosing vallum. The 'ramp' and part of the terrace had been roughly paved, and

I Bradford Antiquary, I91 I. This earthwork, like most of its congeners, yielded nothing to determine the age of its construction and use. The lack of relics in such cases is a normal feature, and at once excludes any theory of residential or military purpose. 
the low vallum served as a backing to the terrace. What appeared to be an external fosse was found to be of superficial character, in no sense defensible, and was probably merely a catch-water extending only round the uphill sector of the enceinte, which lies upon a slight but lengthy slope. ${ }^{1}$ The real character of the work is hinted by the name of the farmstead adjoining, Moot-hill Farm.

The maximum limit of the size of such moot-circles was fixed by that of the human voice. Practical experience shows that the voice cannot be relied upon to carry beyond a distance of some 260-300 ft. ${ }^{2}$ Any ringwork, therefore, of a diameter of 100 yards or less, if otherwise answering to the requirements of the type, may have been a moot-circle. The minimum diameter may have been as little as $35 \mathrm{ft}$.

\section{§ I2. THE RECTANGULAR FORUM.}

The moot-circle described by Homer was that familiar to the Acheans circa 1000 в.c., and the Acheans were an intrusive Celtic race who overran Greece for some 300 years. $^{3}$ They forced their peculiar moot upon Hellas, or part of it, for a time, but it mostly passed away with the race which introduced it, and the traditional rectangular moot of the native Mediterranean race reasserted itself. ${ }^{4}$ In Italy, too, the rectangular moot tended to supplant the circular, whether under the influence of Greek examples, or because here also the Mediterranean race gradually reasserted itself, and side by side with the older Latin circi were to be found rectangular fora of the Roman plan. The same double influence in turn asserted itself in Britain where the circus was, in the case of the more progressive cities, gradually superseded for civil purposes by for a like those of Silchester and elsewhere, remaining in such cases only or chiefly as a place of sport, exactly as had occurred in Rome. But in the less developed communities of Britain, as in those of Italy, the more rudimentary moot, the circus, continued to exist, doing duty for. all municipal purposes.

\footnotetext{
1 There was a similar perfunctory catchwater trench on the up-hill side of the Romano-British ' amphitheatre ' at Charterhouse-on-Mendip.

2 This fact also limited the dimensions
}

of the Greek theatre, likewise evolved from the same original, the sepulchral cruc.

${ }^{3}$ Ridgeway, Early Age of Greece (1901).

4 Vitruvius, v, i, 1 : Graeci in quadrato fora constituunt. 
The change was not so great as at first sight would appear, for though wholly different in external form, the new forum nevertheless preserved the essentials of the older circus. It was a public place. It was also peculiarly sacred, deriving its sanctity - to take by way of example the archetype, the Forum Romanum-from the presence within it of the founder's tomb, the grave of Romulus so-called beneath the Lapis Niger. As close as might be to that source of inspiration met the Comitia Tributa and the far older Comitia Curiata (Calata), the two civil moots which could alone claim to represent the populus as a whole; and here also stood the Rostra and the traditional ancient senatehouse of the community, the Curia Hostilia. This particular part of the Forum was specifically known indeed as the Comitium, a name identical in meaning with áyopá in the local sense of that word. And finally it can scarcely be without significance that the term forum itself retained in Latin speech the special meaning of 'an open place in front of a grave.' 1

\section{§13. FURTHER EVIDENCE.}

The late Dr. Haverfield was willing ${ }^{2}$ to admit that the smaller towns of Roman Britain enjoyed a certain degree of self-government, Professor Sir Paul Vinogradoff has arrived ${ }^{3}$ at the same conclusion upon entirely different evidence, and Festus ${ }^{4}$ supports both. There has not, however, heretofore been recognised any concrete evidence for this self-government. The circi here discussed provide that evidence, for the circus was as much the sign visible of some sort of self-government as is to-day the possession of a town-hall or a parish church.

Literary evidence upon the point, though scanty, is yet not wholly lacking, and, so far as it goes, is valuable. Bede declares 5 that Roman Britain contained 28 'noble cities' besides ' countless' lesser towns. The ' noble cities' perhaps boasted for a, possibly also amphitheatres as such things are usually envisaged, and as we see them at Richborough and

\footnotetext{
${ }^{1}$ See Festus (s.v.), and Cicero de Divin. ii, 20,65 .

Romanization of Britain (1905), p. 21 ; I.C.H. Sbropsbire, i, 120.
}

\footnotetext{
${ }^{3}$ Growtb of the Manor, pp. 45, 46.

${ }^{4}$ S.v. Vicus,

bccles. Hist. I, i, $\$ 5$.
} 
Silchester and Caerlleon; the smaller towns more probably had circi only. This is conjecture, but King Alfred's evidence bears it out: the anfitbeatra of Roman Britain, he says, were 'innumerable.' 1 He wrote the words before A.D. 9or, and we may take it that at that date it was so, especially in his highly Romanised land of Wessex. In the Welsh Triads so-called ' of Dyfnwal Moelmud,' a body of laws dealing particularly with moots and their privileges, the word used for 'moot' is cyrch, i.e. circus in a Welsh form. ${ }^{2}$ The fact proves two things: it proves that the thing was familiar to the Brythonic Welsh under the name of circus ; and it proves that the circus was first and foremost a moot. Finally it may be added that Rowlands ${ }^{3}$ records that the 'amphitheatre' of Llanidan in Anglesey was known as late as 1766 by the name of Bryn Gwyn, a term which he translates as 'Royal Court,' and which, he says, was applied in Welsh poetry to the Houses of Parliament in Westminster.

\section{I4. CHRISTIANITY AND THE CIRCUS.}

The narrow-minded fervour of early Christianity, for reasons of its own confounding the circus with the ampbitheatrum, took especial exception to the circus as the scene of pagan rites. It came to regard the thing as the sign visible of paganism, of diofolgild, and it is in that character that King Alfred mentions and denounces it. Here is the immediate explanation of many things. It explains how and why the real name of the thing came to be so wholly supplanted, and why a large number of circi were converted into mazes. The matter is too large to be here dealt with, but such a conversion certainly occurred, e.g. at Alkborough in Lincs., and probably at Asenby in Yorks. As the maze was a penitential contrivance, or at any rate was made to bear a penitential significance, to convert these diofolgildbus, 'Shrines of the Devil,' into mazes was a perfectly natural way of turning them into what the north-countryman would denominate a 'means,' ${ }^{4}$ i.e. a means of grace.

1 Alfred's Orosius, iii, 3 .

${ }^{2}$ See the Triad, no. xxiii, printed in Myvyrian Arcbaiology.
${ }^{3}$ Mona Antiqua.

${ }^{4}$ A common synonym in Lincolnshire for a chapel. 
Amongst many attempts to explain the name of Maumbury, one of the most imposing of all British circi, one theory would connect it with the word 'mummer,' and see a reference to a supposed performance of medieval miracle-plays within the arena. From what is known of the attitude taken up by Holy Church towards the circi generally, it is highly unlikely that Maumbury was ever used for such a purpose. None the less there may be a real connection with ' mummer,' but in an earlier sense; for the original of 'mummer' was the name of the false prophet Mahomet, and Chaucer still used maumettrie in the sense of diofolgild, the 'worship of false gods.' ${ }^{1}$ As the word may have come into the language at any date subsequent to the Norman Conquest, it may well go back to I 200 or so, at which date there is evidence that Holy Church was still gravely concerned to preach the identity of the circus with paganism.

\section{§ I5. NO UNIFORMITY IN MOOTS.}

It is not suggested that every community of Roman Britain constructed for itself a circus of the type here discussed. The Romans assuredly did not introduce the moot-habit to the British Celts, who had possessed it long years before they came into contact with Rome. They had moots of their own, and some of these at least were crucs, i.e. mounds having very much the appearance of barrows. ${ }^{2}$ Roman influence led a large number of Celtic communities to remodel their earlier moots upon the plan of the circus, as may have happened in the case of Church barrow, or to build a circus of the new fashion side by side with the older cruc; but a great number, amongst smaller communities in particular, or such as lay further away from Roman influence, may well be supposed to have refused to follow the new vogue and to have persisted in using their older traditional moot, of whatever form. Even so there is no reason whatever to question Alfred's express assertion that the number of circi in Britain was unarimede, ' not to be counted.'

\footnotetext{
'Man of Law's Tale, v, 236.

${ }^{2}$ Herein may possibly be the explanation of some of the many 'barrows' which
} 
Lastly, this possible overlap of moots of different forms -of cruc and circus - offers a ready explanation of the fact remarked by Stukeley and Colt Hoare, that the circus is frequently found in close association with barrows. Until the spade shall have tested each individual case it is permissible to believe that some of these barrows so-called are not barrows at all, but merely the earlier moots of their communities. ${ }^{1}$ But even if they should be proved by excavation to be actually barrows, they provide no objection to the theory of the circus here advanced, for the circus being a locus consecratus, nothing would be more natural than that now and again a great man should be buried close beside the spot wherein he had so often sat in council amongst his peers. Roman municipal law, it is true, did not permit of the creation of a new ustrina within 500 paces of the community, ${ }^{2}$ but we do not know how far these smaller communities were affected by any similar law, and still less are we able to determine the date of the building of any particular barrow-with the very rarest exceptions.

\section{§6. POSTSCRIPT.}

Since this article was written there have occurred two further cases to which reference may be made.

The presence on Park Brow in Sompting, Sussex, of a small and somewhat irregular work with a single entrance, but otherwise conforming to type, was a material clue to the discovery (1922) of a lost settlement at the spot, apparently dating from the earliest Iron age continuously down into Romano-British times. ${ }^{3}$ The work lies beside the road leading to the settlement. A trench driven across the area revealed in the centre a shallow pit $2 \mathrm{ft}$. in depth filled in with black soil, amongst which were quantities of greatly comminuted pottery and fragments of bones (bos longifrons), ${ }^{4}$ with two coins of Valentinian I (364-375).

\footnotetext{
1 See, for example, fig. 3, Tarrant Hinton.

${ }^{2}$ See Lex Ursonensis (44 B.c.). Yet Julius Caesar was 'buried' in the Forum, as it were in recognition of his work as Rome's second founder, just as Romulus, its first founder, was believed to be buried under the Lapis Niger in the Comitium. At Megara, says Pausanias (ii, 43,2 ), the tombs
}

of the city's oecists stood actually within the council-chamber.

${ }^{3}$ Sussex Daily News, January 20 and 25 , November $27,1922$.

${ }^{4}$ Similarly Colt Hoare, digging into one of these works, found only 'black earth and fragments of bones, probably the victims of sacrifice' (Ancient Wilts. ii, p. 108). 
An unfossed $60 \mathrm{ft}$. ringwork, with depressed floor and one entrance, lying between the inner and outer lines of the 'camp' of Old Rothbury, Northumberland, had been guessed by Captain Hedley to be a place of meeting. ${ }^{1}$ D. D. Dixon, digging into the centre, at the writer's suggestion, found (1921) a large pit, rudely steyned and filled in with made soil, amongst which were quantities of charcoal and a large shard of extremely coarse pottery pronounced to be of 'early Iron age.'

These two cases, from opposite extremities of England, go far to prove that the British circle-moot surrounded a central botbros analogous to the Ara Consi of the Roman circus, and further hint that in the centre of such circles lies the best chance of finding the clues to their age and their purpose.

\section{\$7. SUMMARY.}

The brief outcome of the matter is as follows:-

There is documentary evidence that every community of Achean, i.e. Celtic Greece, and of Ancient Italy of necessity had its own moot. There is monumental evidence that exactly the same was the case in Celtic Britain. The evidence of both kinds goes to show that such moots were invariably circular or sub-circular, that they bore names philologically identical, that they were in a very special sense loca consecrata, and that they were uniformly modelled upon one or other form of grave. Some were mere mounds after the pattern of the earlier 'bowl' barrow, others resembled the later 'ring' or 'disc' barrows, and all the various forms were in simultaneous use in Britain about the Christian era. The Romans introduced here their own characteristic form of moot, the circus, elliptical in plan and provided with two entrances; and under the influence of Roman example many of the native communities built circi of this form, while others retained the earlier native forms, the circle-moot of strictly circular plan and having one entrance only, or the strictly circular mound-moot.

1 D. D. Dixon, Upter Coquetdale. 